\title{
Impact of the Business Structure on Solvency of Property-Liability Insurance Companies and Its Mediating Effect
}

\author{
Shuang $\mathrm{Wu}^{1}{ }^{1}$ and $\mathrm{Yi} \mathrm{Li} \mathbb{D i D}^{1,2}$ \\ ${ }^{1}$ School of Finance, Hubei University of Economics, Wuhan 430205, Hubei, China \\ ${ }^{2}$ Research Center for Risk, Wuhan University, Wuhan 430072, Hubei, China \\ Correspondence should be addressed to Yi Li; liyi_hbue@126.com
}

Received 7 May 2021; Revised 22 June 2021; Accepted 30 July 2021; Published 10 August 2021

Academic Editor: Guangdong Wu

Copyright (C) 2021 Shuang Wu and Yi Li. This is an open access article distributed under the Creative Commons Attribution License, which permits unrestricted use, distribution, and reproduction in any medium, provided the original work is properly cited.

\begin{abstract}
It is an important objective for insurers to optimize their business structures to prevent business risks. This paper examines the solvency risk management in property-liability insurance companies from the perspective of business structure optimization. We construct a logical framework to explain the impact of the business structure on solvency through profitability and reinsurance behavior of property-liability insurance companies. By constructing a mediating effect model, we tested 35 Chinese-funded property-liability insurance companies and 18 foreign-funded property-liability insurance companies in China's insurance market from 2009 to 2015. Two major results were found as follows: first, the impact of the business structure on solvency is positively significant in small Chinese-funded insurance companies as well as foreign-funded insurance companies, while it is insignificant in large Chinese-funded insurance companies. Second, the mediating effect test shows that the intermediary channel of profitability does not exist, while the intermediary channel of reinsurance exists, and the reinsurance fully mediated the relationship between business structure and solvency only in foreign-funded insurance companies. Therefore, we suggest that small Chinese-funded insurance companies should actively develop nonauto insurance and improve the risk diversification effect of the diversified business structure. On the contrary, foreign-funded insurance companies should give play to their differentiated advantages and continue to concentrate on the operation of nonauto insurance in China's insurance market. Besides, the above two types of companies should attach more importance to the positive role of reinsurance in solvency risk management in their business development strategies.
\end{abstract}

\section{Introduction}

As we all know, insurance is a "social stabilizer" and "economic booster," and the key to give full play to the economic compensation function of insurance is the insurance product supply. Optimizing the product supply of insurance companies can not only meet the diversified needs of risk transfer of social and economic units but also help to improve the risk prevention and control ability of insurance companies themselves. In China's insurance industry's " 11 th Five-Year Plan," "12th Five-Year Plan," and "13th Five-Year Plan" (The "11th Five-Year Plan" of China's insurance industry refers to the Outline of the "11th Five-Year" Plan for the Development of China's Insurance Industry, which sets forth policies and measures for the development of China's insurance industry from 2006 to 2010, including its development direction, expected goals, and targets. The "12th Five-Year Plan" and "13th Five-Year Plan" of the insurance industry refer to the Outline of the 12th Five-Year Plan for the Development of China's Insurance Industry and the Outline of the 13th Five-Year Plan for the Development of China's Insurance Industry, respectively.), business structure optimization of property-liability $(\mathrm{P} / \mathrm{L})$ insurance companies has been repeatedly taken as the top priority in the reform and development of China's insurance market. For one thing, the overdependence on auto insurance business in Chinesefunded $\mathrm{P} / \mathrm{L}$ insurance companies is not conducive to the diversification of their own operating risks and reduces the 
industry's overall resistance to market risks. For another thing, due to the initial operating restrictions, foreignfunded $\mathrm{P} / \mathrm{L}$ insurance companies (According to the Regulations on the Administration of Foreign-Funded Insurance Companies issued by the China Banking and Insurance Regulatory Commission, foreign-funded companies include both wholly foreign-owned $\mathrm{P} / \mathrm{L}$ insurance companies established in China and joint-venture $\mathrm{P} / \mathrm{L}$ insurance companies with more than $25 \%$ foreign shares. Therefore, this paper divides the research samples into foreign-funded and Chinese-funded $\mathrm{P} / \mathrm{L}$ insurance companies according to the above provisions.) cannot display their ambitions in China's auto insurance market and have to turn to the nonauto insurance business.

Therefore, a series of reform measures for auto insurance business have been implemented gradually. For example, the foreign-funded insurance company was allowed to enter the compulsory traffic accident liability insurance (CTALI) market from 2012; the second round of market-oriented reform of commercial auto insurance rate was executed from 2015. In 2018, the China Banking and Insurance Regulatory Commission (CBIRC) began to require insurers to strictly follow the regulations reported to the regulatory authorities in handling fees in practice. Under this background, Chinese-funded and foreign-funded $\mathrm{P} / \mathrm{L}$ insurance companies chose different business development strategies, and their business structures began to change.

As shown in Figure 1, after foreign-funded P/L insurance companies entered the CTALI market in 2012, the proportion of auto insurance businesses increased, while large Chinese-funded P/L insurance companies (Referred to the practice of Guo and Wang, this paper divides large and small Chinese-funded insurance companies based on the median premium income. Insurers whose premium income is greater than the median of their premium income are considered as large companies, while those whose premium income is less than the median of their premium income are considered as small companies.) actively seized the opportunities after the release of the "New Ten Policies" (In 2014, the State Council of the People's Republic of China issued Several Opinions on Accelerating the Development of the Modern Insurance Service Industry, referred to as the "New Ten Policies.") to accelerate the development of their nonauto insurance business, and the proportion of nonauto insurance businesses increased gradually. However, small Chinese-funded P/L insurance companies still maintained their development strategy of auto insurance, and the proportion of nonauto insurance business is still on the decline.

In most countries, solvency regulation is the core tool used in insurance regulatory systems. Especially in China, it is one of the three regulatory pillars in the insurance industry, and it is the major risk prevention method for insurance companies. The $\mathrm{P} / \mathrm{L}$ insurance companies should not threaten their own solvency when developing nonauto insurance or auto insurance business. In December 2016, the CBIRC issued Guidelines on Insurance Product Development for Property-Liability Insurance Companies, which clearly pointed out that an insurer shall comprehensively consider

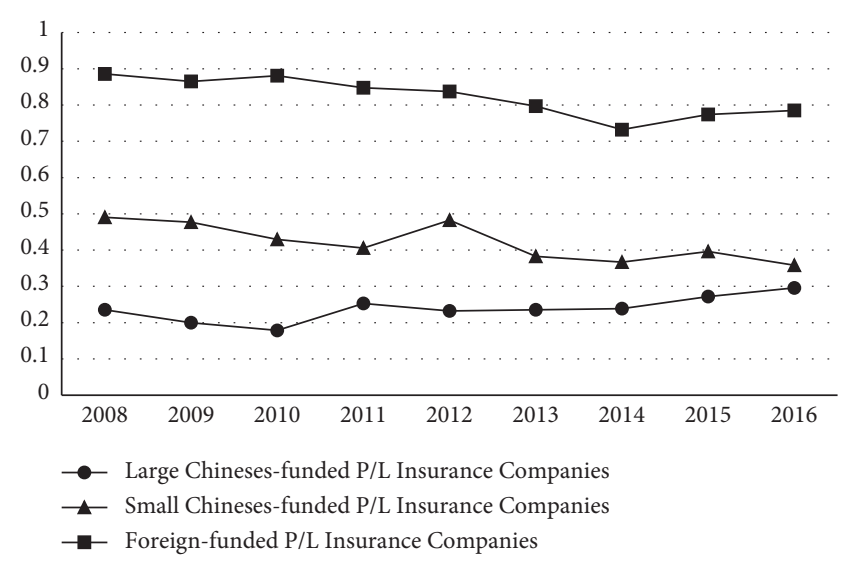

Figure 1: The changing trend of the average proportion of nonauto insurance business of $\mathrm{P} / \mathrm{L}$ insurance companies in China. Data source: through 2009-2017 China Insurance Statistical Yearbook collation.

its underwriting capacity, division of risk units, reinsurance support, and other factors in the development of insurance products and shall not endanger its solvency and financial soundness.

Therefore, is there any impact of the business structure on solvency in $\mathrm{P} / \mathrm{L}$ insurance companies? Are there any differences in these impacts between Chinese-funded and foreign-funded $\mathrm{P} / \mathrm{L}$ insurance companies in China? If the answers of the above questions are both yes, through which channels the business structure affects the solvency among different companies? To answer all these questions, this paper discussed the impact of business structures on solvency in different $\mathrm{P} / \mathrm{L}$ insurance companies through the profitability channel and the reinsurance channel by building an intermediary model.

\section{Literature Review and Research Hypothesis}

In early years, scholars mainly focused on the factors that influence the solvency in insurance companies. For example, Harrington and Nelson [1] empirically examined the factors that influence the solvency of insurers and found that factors such as premium surplus ratio, asset structure, and business structure all affect the insurers' solvency. Zhu et al. [2] pointed out that business quality was an important factor that affects the solvency of an insurer. Recently, more and more studies have begun to explore the influence of the business structure on the insurers' solvency. Jiang and Liu [3] came out with the conclusion that unbalanced product mix had a negative impact on the solvency.

There are two main streams on the mechanism of how the business structure affects the insurers' solvency. One is the profitability channel, and the other is the reinsurance channel as we can see as follows.

2.1. The Impact of the Business Structure on Solvency through the Profitability Channel. According to the synergistic effect theory first put forward by the American enterprise strategic management expert Ansoff [4], business diversification can 
reduce costs, increase sales, and thus improve corporate earnings. The development of nonauto insurance business by $\mathrm{P} / \mathrm{L}$ insurance companies can increase their profitability by sharing resources with auto insurance business. Therefore, according to the synergistic effect theory, the transformation of $\mathrm{P} / \mathrm{L}$ insurance companies from a single business structure to a diversified business structure is conducive to improving their profitability.

However, according to the principal-agent theory proposed by Berle and Means in the 1930s, diversified business structure also means that, for the enterprise management level of diversification, as a result of the information asymmetry, diversification is likely to increase the insurance company's supervision and control difficulty and reduce the effectiveness of the enterprise management strategy and decision-making thereby weakening the profitability of the insurance company.

On the basis of the above theories, many scholars have studied the impact of business structure diversification on profitability of $\mathrm{P} / \mathrm{L}$ insurance companies but reached inconsistent conclusions. Teyssier [5], Meador et al. [6], and Pervan and Pavic Kramaric [7] proved that the diversification of business structure has a positive effect on the profitability of $\mathrm{P} / \mathrm{L}$ insurance companies. However, studies conducted by Hoyt and Trieschmann [8], Cummins and Nini [9], Cummins et al. [10], and Shim [11] all support that business diversification will reduce the profitability of $\mathrm{P} / \mathrm{L}$ insurance companies. Elango et al. [12] even believed that there may be a complex nonlinear relationship between the two.

In the literature on factors affecting the solvency of insurance companies, many scholars have found that the profitability is an important factor, and the improvement of profitability helps to enhance the solvency of $\mathrm{P} / \mathrm{L}$ insurance companies. Ambrose and Seward [13] considered the profit margin, company size, investment return, and other internal factors of $\mathrm{P} / \mathrm{L}$ insurance companies as important variables affecting their solvency. Leadbetter and Dibra [14] found that the financial market turmoil and the decline of the profitability of the industry were catalysts for the solvency insufficiency of Canadian P/L insurance companies from 1960 to 2005. Kleffner and Lee [15] studied the reasons for the low incidence of insolvency of $\mathrm{P} / \mathrm{L}$ insurance companies in Canada, found that only the measure of profitability, namely, return on assets, was a significant indicator, and pointed out that this conclusion was consistent with many studies taking $\mathrm{P} / \mathrm{L}$ insurance companies in the United States as samples. Yakob et al. [16] also found in their study of life insurance companies that the improvement of profitability can enhance the solvency. $\mathrm{Li}$ and $\mathrm{Lu}$ [17] studied the solvency crisis of $\mathrm{P} / \mathrm{L}$ insurance companies and solutions from the perspective of performance analysis based on the data of 13 Chinese-funded and foreign-funded $\mathrm{P} / \mathrm{L}$ insurance companies and pointed out that the low return on assets was an important reason for the solvency crisis of Chinesefunded P/L insurance companies. Zhu et al. [2] argued that the actual solvency was affected by changes in owners' equity, while the profitability had a direct impact on such changes. The authors further studied the influence of 8 internal factors and 3 external factors on solvency by taking $10 \mathrm{P} / \mathrm{L}$ insurance companies in China as samples and found that return on assets was significantly positively correlated with solvency. Zheng [18] selected the data of insurance companies in China from 2007 to 2012, found that the net interest rate on assets was significantly positively correlated with the solvency of insurance companies, and proposed that insurers should enhance their solvency from the aspects of product structure and profitability improvement. Based on the data of 14 China's P/L insurance companies from 2012 to 2017, $\mathrm{Li}$ and $\mathrm{Gu}$ [19] did not find a significant correlation between the net profit margin of $\mathrm{P} / \mathrm{L}$ insurance companies and solvency and pointed out that $\mathrm{P} / \mathrm{L}$ insurance companies should reduce the loss ratio and asset-liability ratio, rather than excessively pursue the improvement of profitability to enhance solvency.

To sum up, changes in the business structure of $\mathrm{P} / \mathrm{L}$ insurance companies will affect their profitability, which is an important factor affecting their solvency. Therefore, we put forward the first hypothesis.

Hypothesis 1. The business structure of a $\mathrm{P} / \mathrm{L}$ insurance company affects its solvency through the profitability channel.

\subsection{The Influence of the Business Structure on Solvency through} the Reinsurance Channel. The business structure of an insurance company will affect its reinsurance behavior. Many research studies on insurers' reinsurance behavior have found that business structure is an important determinant. Mayers and Smith believed that the increase of business concentration of insurance companies would increase the cash flow volatility and the probability of insufficient solvency, and reinsurance was an important means to solve the insolvency caused by the above factors [20]. Based on the panel data of insurance companies in Croatia, Curak et al. [21] found that when the business structure of insurance companies is more concentrated, insurance companies tend to increase the proportion of reinsurance ceding so as to transfer more risk to the reinsurance companies. However, Mankaï and Belgacem [22] believed that $\mathrm{P} / \mathrm{L}$ insurance companies could gain economic benefits from specialized operations so as to reduce their demand for reinsurance, and empirical studies with the American $\mathrm{P} / \mathrm{L}$ insurance companies as samples also proved that business concentration was significantly negatively correlated with reinsurance rate.

In the empirical studies on reinsurance demand of insurance companies in China, most of the research conclusions support that the more concentrated the business structure of insurance companies is, the lower their reinsurance demand will be. Wu et al. [23] used the fixed effect model to conduct an empirical study on $\mathrm{P} / \mathrm{L}$ insurance companies in China from 2001 to 2007 and found that business concentration was significantly positively correlated with the reinsurance ceding ratio of $\mathrm{P} / \mathrm{L}$ insurance companies, indicating that business concentration was an important consideration in reinsurance decision-making. Zhao and $\mathrm{Wu}$ [24] used the quantile regression method to 
study the relationship between business concentration and reinsurance demand of $\mathrm{P} / \mathrm{L}$ insurance companies and found that, except for the extreme positions (0.05 and 0.95), business concentration of $\mathrm{P} / \mathrm{L}$ insurance companies was negatively correlated with reinsurance demand in general. The more dispersed the business structure of an insurance company is, the more professional reinsurance services are needed due to the limitations of professional knowledge, information, and management experience. When Chen and Ding [25] empirically tested the impact of business concentration on reinsurance demand of $\mathrm{P} / \mathrm{L}$ insurance companies in China, they found that the more concentrated the business structure is, the lower the reinsurance ceding ratio will be. The authors further pointed out that this is closely related to the fact that most of the business structures of $\mathrm{P} / \mathrm{L}$ insurance companies in China are concentrated in auto insurance, and the risk of auto insurance business is lower than that of nonauto insurance business such as liability insurance and cargo transportation insurance, so the reinsurance demand is also lower.

Reinsurance is an important means of risk transfer for insurance companies. The control of underwriting capacity is an important factor affecting the solvency of an insurance company. On the one hand, insurance companies can purchase reinsurance to transfer insurance risks that they cannot bear to reinsurance companies so as to improve their solvency. On the other hand, a high reinsurance ratio means the increase of reinsurance premium and the decrease of underwriting income, which is not conducive to the accumulation of corporate capital and may have an adverse impact on solvency. Lin et al. [26] and Liang and Huang [27] studied how insurance companies determine the optimal reinsurance ceding ratio to ensure their solvency. Most empirical studies based on Chinese data have found that an increase in the reinsurance cession ratio can improve the solvency of insurance companies. Zhu et al. [2] and Huang and Wang [28] found in their empirical studies based on Chinese data that increasing reinsurance ratio can enhance the solvency of insurance companies.

To sum up, the business structure of $\mathrm{P} / \mathrm{L}$ insurance companies will affect their reinsurance ceding ratio, and the increase of reinsurance ceding ratio can enhance their solvency. Therefore, we propose the second hypothesis of this paper.

Hypothesis 2. The business structure of a $\mathrm{P} / \mathrm{L}$ insurance company affects its solvency through the reinsurance channel.

According to the above analysis, profitability and reinsurance behavior are important channels for $\mathrm{P} / \mathrm{L}$ insurance companies' business structure to affect solvency. The specific influence mechanism of the business structure of $\mathrm{P} / \mathrm{L}$ insurance companies affecting solvency is shown in Figure 2.

\section{Research Design}

3.1. The Data Source. The research samples of this paper are the P/L insurance companies in China from 2009 to 2015. The sample period is selected from 2009, mainly because the solvency adequacy ratio data obtained on the website of China's Insurance Industry Association began in 2009 at the earliest. The reason why 2015 is chosen as the cutoff date is that China's insurance industry has officially implemented the "China Risk-Oriented Solvency System" since 2016, so there will be a difference between the calculation of solvency adequacy ratio after 2016 and before 2016. Therefore, in order to ensure the consistency and comparability of the research samples, the sample cutoff date is selected as 2015 . The sample data are from the database of CSMR (China Stock Market \& Accounting Research Database) and China Insurance Yearbook from 2009 to 2016. The solvency adequacy ratio data are manually sorted out from the annual reports of various insurance companies published on the website of the Insurance Industry Association. The macrodata are obtained from the website of the National Bureau of Statistics of the People's Republic of China. In this paper, policy-based P/L insurance companies (such as China Export and Credit Insurance Corporation), Lloyd's, professional insurance companies, and captive insurance companies are deleted, and the key indicators of this paper are winsorized by $1 \%$. Table 1 reports descriptive statistics of the main variables in the full sample and the subsample of Chinese-funded and foreign-funded $\mathrm{P} / \mathrm{L}$ insurance companies.

\subsection{Variable Selection}

\subsubsection{Explained Variable}

(1) Solvency. In this paper, according to Bian and Wang [29], solvency adequacy ratio was selected to reflect the solvency of $\mathrm{P} / \mathrm{L}$ insurance companies. Solvency adequacy ratio is the ratio of "actual capital" to "minimum capital" of an insurer, which reflects an insurer's ability to fulfill its policy liability. The larger the solvency adequacy ratio is, the stronger the insurer's solvency is.

\subsubsection{Explanatory Variable}

(1) Business Structure. In this paper, the definition of the business structure of $\mathrm{P} / \mathrm{L}$ insurance companies is based on the following three aspects: first, the difference of risk characteristics between auto insurance and nonauto insurance: different from the auto insurance, the types of risks insured by the nonauto insurance are more complex and special, and even many risks have the characteristics of long tail, such as liability insurance and catastrophe insurance. Once the loss occurs, it will bring huge indemnity payout to the $\mathrm{P} / \mathrm{L}$ insurance company. Therefore, it is more difficult for $\mathrm{P} / \mathrm{L}$ insurance companies to underwrite and settle claims for nonauto insurance objects, and the compensation volatility is relatively large.

Second, refer to the definition of the business structure in the banking industry. A bank's business structure usually refers to the proportion of noninterest income or interest income in the bank's income structure. At the beginning of its development, the banking industry also relied on interest income as its main source of income. However, drived by the needs of social and economic development, the income 


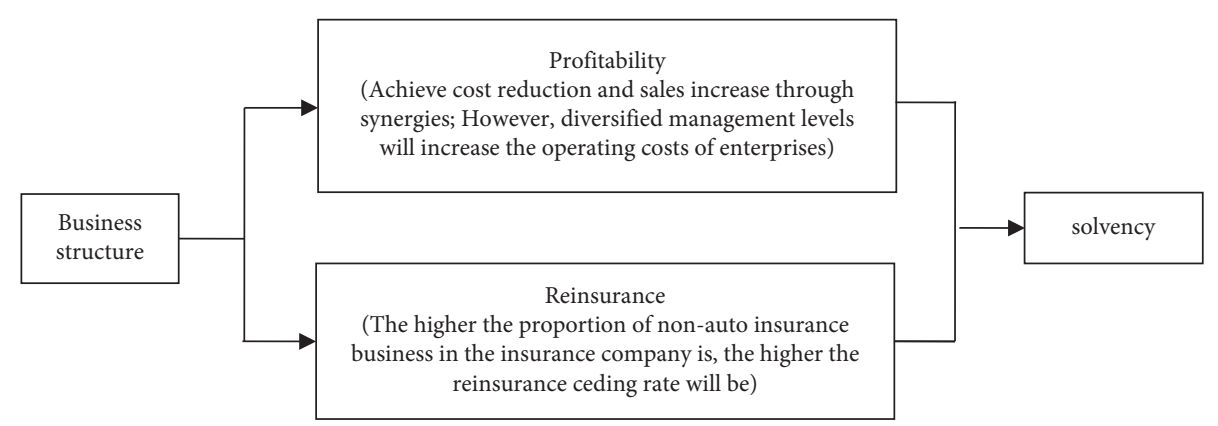

FIgURE 2: The transmission path of the impact of the business structure of $\mathrm{P} / \mathrm{L}$ insurance companies on solvency.

Table 1: Descriptive statistics.

\begin{tabular}{|c|c|c|c|c|c|c|}
\hline & Variable & $\begin{array}{l}\text { Sample } \\
\text { size }\end{array}$ & $\begin{array}{l}\text { Mean } \\
\text { value }\end{array}$ & $\begin{array}{l}\text { Standard } \\
\text { deviation }\end{array}$ & $\begin{array}{c}\text { Minimum } \\
\text { value }\end{array}$ & $\begin{array}{c}\text { Maximum } \\
\text { value }\end{array}$ \\
\hline \multirow{11}{*}{ Full sample } & Solvency & 325 & 18.91 & 67.63 & 0.52 & 898.4 \\
\hline & Nonauto & 451 & 0.486 & 0.357 & 0.013 & 1 \\
\hline & Roa & 448 & -0.017 & 0.067 & -0.399 & 0.299 \\
\hline & Rein & 450 & 0.228 & 0.234 & 0 & 0.971 \\
\hline & Size & 448 & 8.079 & 1.660 & 5.188 & 13.59 \\
\hline & Loss & 393 & 0.438 & 0.431 & 0 & 6.880 \\
\hline & Lev & 448 & 0.616 & 0.211 & 0.018 & 1.297 \\
\hline & Geodiv & 450 & 0.609 & 0.362 & 0 & 0.959 \\
\hline & Invest & 440 & 0.651 & 0.196 & 0.137 & 0.985 \\
\hline & GDP & 454 & 12.90 & 0.758 & 10.99 & 13.52 \\
\hline & Interest & 454 & 2.412 & 0.694 & 1.022 & 3.325 \\
\hline \multirow{11}{*}{$\begin{array}{l}\text { Sample of Chinese-funded P/L insurance } \\
\text { companies }\end{array}$} & Solvency & 209 & 14.30 & 50.10 & 0.52 & 315.5 \\
\hline & Nonauto & 273 & 0.270 & 0.196 & 0.013 & 0.971 \\
\hline & Roa & 270 & -0.006 & 0.056 & -0.399 & 0.084 \\
\hline & Rein & 272 & 0.113 & 0.103 & 0 & 0.734 \\
\hline & Size & 270 & 8.910 & 1.541 & 6.189 & 13.59 \\
\hline & Loss & 235 & 0.435 & 0.159 & 0 & 0.779 \\
\hline & Lev & 270 & 0.644 & 0.201 & 0.018 & 0.959 \\
\hline & Geodiv & 273 & 0.778 & 0.284 & 0 & 0.959 \\
\hline & Invest & 264 & 0.267 & 0.169 & 0.015 & 0.762 \\
\hline & GDP & 275 & 12.90 & 0.767 & 10.99 & 13.52 \\
\hline & Interest & 275 & 2.423 & 0.685 & 1.022 & 3.325 \\
\hline \multirow{11}{*}{$\begin{array}{l}\text { Sample of foreign-funded } \mathrm{P} / \mathrm{L} \text { insurance } \\
\text { companies }\end{array}$} & Solvency & 116 & 27.21 & 90.77 & 1.077 & 898.4 \\
\hline & Nonauto & 178 & 0.817 & 0.289 & 0.053 & 1 \\
\hline & Roa & 178 & -0.035 & 0.077 & -0.308 & 0.299 \\
\hline & Rein & 178 & 0.404 & 0.267 & 0.001 & 0.971 \\
\hline & Size & 178 & 6.817 & 0.834 & 5.188 & 9.325 \\
\hline & Loss & 158 & 0.442 & 0.653 & 0 & 6.880 \\
\hline & Lev & 178 & 0.574 & 0.219 & 0.020 & 1.297 \\
\hline & Geodiv & 177 & 0.349 & 0.315 & 0 & 0.922 \\
\hline & Invest & 176 & 0.473 & 0.169 & 0.053 & 0.863 \\
\hline & GDP & 179 & 12.90 & 0.746 & 10.99 & 13.52 \\
\hline & Interest & 179 & 2.396 & 0.709 & 1.022 & 3.325 \\
\hline
\end{tabular}

structure of banks began to shift from interest income to noninterest income, and the business structure of banks shifted from centralization to diversification. The business operation status of $\mathrm{P} / \mathrm{L}$ insurance companies in China is similar to that of the banking industry. Their profit model is also shifting from the traditional auto insurance business to actively explore nonauto insurance business.

Third, in view of the existing literature on the definition of $\mathrm{P} / \mathrm{L}$ insurance company business structure and the status quo of $\mathrm{P} / \mathrm{L}$ insurance company's business structure in China, based on the current situation that the auto insurance business accounts for as high as $66.97 \%$ in China's $\mathrm{P} / \mathrm{L}$ insurance market, Hao [30] pointed out that it is more reasonable to measure the business structure by the proportion of the largest insurance in the premium income, compared with the previous studies to measure the business structure of $\mathrm{P} / \mathrm{L}$ insurance companies by using the Herfindahl index or entropy index.

This paper focuses on the problem of the business structure of China's P/L insurance companies. Therefore, we 
define the business structure as the proportion of nonauto insurance business, that is, the proportion of the nonauto insurance business income in the total premium income.

\subsubsection{Intermediary Variables}

(1) Profitability. This paper uses the return on assets to measure the profitability of a $\mathrm{P} / \mathrm{L}$ insurance company. Return on assets is one of the most widely used indicators to measure the profitability of insurance companies. Return on assets represents the ability of an enterprise to obtain income of all its assets and comprehensively reflects the profitability and input-output status of an enterprise.

(2) Reinsurance. This paper uses the reinsurance ratio to reflect the reinsurance behavior of insurance companies. The reinsurance ratio of an insurance company is equal to the ratio of the premium ceded by the insurance company and the income from insurance business. The larger the reinsurance ratio is, the greater the proportion of insurance risks that the insurance company distributes through reinsurance.

3.2.4. Control Variables. Based on the relevant research on solvency and availability of the data, this paper controls other factors that may affect the solvency of $\mathrm{P} / \mathrm{L}$ insurance companies, such as the company's own characteristics, daily business activities, and macroeconomic factors. Specifically, it includes the following variables.

(1) The Company Size. This paper uses the natural logarithm of the total assets of $\mathrm{P} / \mathrm{L}$ insurance companies as the measurement index of company size. Company size is an important microfactor affecting the solvency of insurance companies. Larger insurers are able to take advantage of economies of scale, with richer cash flows and greater solvency. In addition, compared with large insurance companies, small insurance companies are more likely to suffer from solvency crisis because regulators are less likely to wind down and liquidate large insurance companies.

(2) Loss Ratio. The loss ratio is the ratio of claims to premium income. Too high a loss ratio will result in a large outflow of cash flow and a reduction in the solvency reserves made up of capital, total reserves, and unallocated earnings, thus reducing solvency [17]. The empirical studies of $\mathrm{Li}$ and $\mathrm{Gu}$ [19] all confirm that an increase in the loss ratio of an insurance company will significantly reduce its solvency.

(3) Financial Leverage. Corporate financial leverage is usually measured by asset-liability ratio, which is equal to the ratio of total liabilities and total assets. Asset structure has a great impact on an insurer's solvency, and asset-liability ratio is an important reflection of the asset structure of an insurer. Yakob et al. [16] found that the asset-liability ratio was significantly negatively correlated with the insurer's solvency. However, Harrington and Nelson [1] believed that the asset-liability ratio is a reflection of a company's long-term solvency. Since longterm liabilities do not need to be paid in the short term, on the contrary, it will improve the cash flow of an insurance company. Therefore, the higher the asset-liability ratio is, the stronger the solvency of an insurance company will be.

(4) Geographic Diversification. We use the complement of the Herfindahl index of premium income across 23 provinces, 4 municipalities directly under the central government, and 5 autonomous regions as the geographic diversification measure. The formula to calculate the geographic diversification is as follows:

$$
\operatorname{geodiv}_{t}=1-\sum_{i=1}^{n}\left(\frac{\text { income }_{i, j, t}}{\text { income }_{i, t}}\right)^{2},
$$

where the income ${ }_{i, j, t} /$ income $_{i, t}$ refers to the proportion of the $i$-th $\mathrm{P} / \mathrm{L}$ insurance company's premium income from the $j$-th province, municipality and city specifically designated in the state plan to the total premium income of the $i$-th $\mathrm{P} / \mathrm{L}$ insurance company in the period $t$.

The larger geodiv is, the more geographically diversified the $\mathrm{P} / \mathrm{L}$ insurer is. Insurance companies implement the strategy of geographic diversification and diversify risks within the geographical scope, which may also have a certain impact on their solvency, just as business diversification.

(5) Stable Investment Assets. Referring to the practice of Sun and Cui [31], this paper uses the proportion of less risky investment assets such as cash, time deposit, and real estate investment in the investment portfolio of insurance companies to measure the proportion of stable investment assets of $\mathrm{P} / \mathrm{L}$ insurance companies. Zhu et al. [2] pointed out that the solvency of aggressive and conservative companies is different. The higher the proportion of stable investment assets is, the smaller the investment risk an insurance company faces and the less likely the insurance company is to have a solvency crisis. However, on the contrary, according to the investment principle of "high risk brings high return," less investment risk means lower investment return, and lower investment return is not conducive to the improvement of solvency of insurance companies.

(6) Gross Domestic Product. In addition to the above microfactors, the impact of macroeconomy on the insurers' solvency is also very important. In this paper, the natural log of GDP is selected as the control variable and put into the model.

(7) Market Interest. The level of market interest rate will affect the return on investment of an insurer, thus affecting its solvency adequacy ratio. This paper refers to the practice of Peng and Zeng [32] to represent the market interest rate with the Shanghai Interbank Offered Rate.

The definitions of the main variables selected in this paper are shown in Table 2.

3.3. Model Specification. According to Baron and Kenny's [33] stepwise test regression coefficient method for the judgment of mediating effect, the setting of the mediating effect model needs to be divided into three steps. 
TABLE 2: Main variable definitions.

\begin{tabular}{lcc}
\hline Variable type & Variable name & Variable definitions \\
\hline $\begin{array}{l}\text { Explained variable } \\
\text { Explanatory variable }\end{array}$ & Solvency & Solvency, solvency adequacy ratio \\
Intermediary variable & Roa & Business structure, proportion of nonauto insurance income to total premium income \\
& Rein & Profitability, the return on assets \\
Size & Reinsurance, the ratio of ceding premium to income from insurance business \\
Loss & Company size, natural log of total assets \\
Lev & Leoss ratio, the ratio of claims to premium income \\
Gontrol variable & Invest & Financial leverage, the ratio of total liabilities to total assets \\
& GDP & Geographic diversification, Herfindahl index
\end{tabular}

Step 1. Regression of independent variables to dependent variables.

Step 2. Regression of independent variables to intermediary variables.

Step 3. Simultaneous regression of independent variables and intermediary variables to dependent variables.

According to the above theoretical hypothesis, the business structure of $\mathrm{P} / \mathrm{L}$ insurance companies may affect their solvency through two ways: profitability and reinsurance behavior. In this section, the stepwise regression method is used to examine the ways in which the business structure of $\mathrm{P} / \mathrm{L}$ insurance companies affects solvency.

$$
\begin{array}{r}
\text { solvency }_{i, t}=\alpha_{0}+\alpha_{1} \text { nonauto }_{i, t}+\alpha_{2} \operatorname{control}_{i, t}+\mu_{i, t}, \\
m_{i, t}=\beta_{0}+\beta_{1} \text { nonauto }_{i, t}+\beta_{j} \operatorname{control}_{i, t}+\varepsilon_{i, t},
\end{array}
$$

solvency $_{i, t}=\varphi_{0}+\varphi_{1}$ nonauto $_{i, t}+\varphi_{2} m_{i, t}+\varphi_{j} \operatorname{control}_{i, t}+\omega_{i, t}$,

where solvency $y_{i, t}$ is the solvency adequacy ratio of the $i$ th $\mathrm{P} / \mathrm{L}$ insurer in period $t$, nonauto $_{i, t}$ is the proportion of nonauto insurance business of the $i$ th $\mathrm{P} / \mathrm{L}$ insurer in period $t$, and $m_{i, t}$ is the intermediary variable. control $_{i, t}$ is a series of control variables including company size, loss ratio, financial structure, geographic diversification, and stable investment assets. $\varepsilon_{i, t}, \mu_{i, t}$, and $\omega_{i, t}$ are the residual terms, respectively.

First, the regression coefficient $\alpha_{1}$ in model (2) is tested. If $\alpha_{1}$ is significant, further verification will be carried out; otherwise, the test is terminated. On the basis of the significance of $\alpha_{1}$, the regression coefficient $\beta_{1}$ in model (3) and the regression coefficients $\varphi_{1}$ and $\varphi_{2}$ in model (4) were further verified. If coefficients $\beta_{1}$ and $\varphi_{2}$ were both significant at the same time, there was a mediating effect.

\section{Empirical Process and Result Analysis}

4.1. Descriptive Statistics of Variables. Table 1 lists the descriptive statistical results of the relevant variables. In the sample period, the average solvency adequacy ratio of $\mathrm{P} / \mathrm{L}$ insurance companies is 18.91 , and the average proportion of nonauto insurance business is 0.486 . In general, the proportion of auto insurance business is still relatively high.

According to the subsample descriptive statistics, the average solvency adequacy ratio of Chinese-funded $\mathrm{P} / \mathrm{L}$ insurance companies is 14.30 , which is lower than the average solvency ratio of foreign-funded $\mathrm{P} / \mathrm{L}$ insurance companies of 27.21. The average proportion of nonauto insurance business of Chinese-funded $\mathrm{P} / \mathrm{L}$ insurance companies is 0.270 , while the average proportion of nonauto insurance business of foreign-funded $\mathrm{P} / \mathrm{L}$ insurance companies is as high as 0.817 . Consistent with the above analysis, the business structure of Chinese-funded $\mathrm{P} / \mathrm{L}$ insurance companies is mainly focused on auto insurance business, while that of foreign-funded $\mathrm{P} / \mathrm{L}$ insurance companies is mainly focused on nonauto insurance business. In terms of return on assets, it is consistent with the findings of Hao [30] that the average return on assets of $\mathrm{P} / \mathrm{L}$ insurance companies in China is negative. However, the average return on assets of Chinese-funded $\mathrm{P} / \mathrm{L}$ insurers is -0.006 , which is better than the average of foreign-funded $\mathrm{P} / \mathrm{L}$ insurers, which is -0.035 . As for reinsurance ceding, the average reinsurance rate of Chinese-funded $\mathrm{P} / \mathrm{L}$ insurance companies is 0.113 , which is lower than that of foreign-funded $\mathrm{P} / \mathrm{L}$ insurance companies, which is 0.404 . As for the geographical diversification, the average degree of Chinese-funded $\mathrm{P} / \mathrm{L}$ insurance companies is 0.778 , which is much larger than that of foreign-funded $\mathrm{P} / \mathrm{L}$ insurance companies, which is only 0.349 . In terms of financial leverage, the average financial leverage of Chinese-funded $\mathrm{P} / \mathrm{L}$ insurance companies is 0.644 , higher than the average of foreignfunded $\mathrm{P} / \mathrm{L}$ insurance companies. In terms of stable investment assets, the average value of foreign-funded $\mathrm{P} / \mathrm{L}$ insurance companies is 0.473 , while the average value of Chinese-funded $\mathrm{P} / \mathrm{L}$ insurance companies is 0.267 , indicating that foreign-funded $\mathrm{P} / \mathrm{L}$ insurance companies are relatively more stable in the insurance fund investment.

4.2. Basic Result of the Impact of the Business Structure on Solvency. Table 3 empirically tests the regression results of the impact of the business structure on solvency through the panel fixed effect model. Column (1) in Table 3 shows the empirical results of the full sample, and columns (2) and (5) show the 
TABLE 3: The impact of the business structure of $\mathrm{P} / \mathrm{L}$ insurance companies on solvency.

\begin{tabular}{|c|c|c|c|c|c|}
\hline Variables & $\begin{array}{l}\text { Full sample } \\
\text { (1) }\end{array}$ & $\begin{array}{l}\text { Chinese-funded } \\
\text { (2) }\end{array}$ & $\begin{array}{l}\text { Large Chinese-funded } \\
\text { (3) }\end{array}$ & $\begin{array}{l}\text { Small Chinese-funded } \\
\text { (4) }\end{array}$ & $\begin{array}{l}\text { Foreign-funded } \\
\text { (5) }\end{array}$ \\
\hline Nonauto & $\begin{array}{c}182.025 * * * \\
(5.871)\end{array}$ & $\begin{array}{c}126.532 * * * \\
(4.900)\end{array}$ & $\begin{array}{c}0.866 \\
(0.078) \\
\end{array}$ & $\begin{array}{c}160.839 * * * \\
(3.938)\end{array}$ & $\begin{array}{c}278.471 * * * \\
(4.166)\end{array}$ \\
\hline Size & $\begin{array}{c}18.535 * * \\
(2.076) \\
\end{array}$ & $\begin{array}{c}1.793 \\
(0.271) \\
\end{array}$ & $\begin{array}{c}4.471 * * * \\
(3.626) \\
\end{array}$ & $\begin{array}{c}8.991 \\
(0.595)\end{array}$ & $\begin{array}{c}62.998 * * \\
(2.608)\end{array}$ \\
\hline Loss & $\begin{array}{c}0.149 \\
(0.020)\end{array}$ & $\begin{array}{c}-60.020 * * * \\
(-2.817)\end{array}$ & $\begin{array}{c}-3.999 \\
(-0.764) \\
\end{array}$ & $\begin{array}{c}-91.854 * * \\
(-2.328) \\
\end{array}$ & $\begin{array}{c}0.087 \\
(0.008) \\
\end{array}$ \\
\hline Lev & $\begin{array}{c}-73.310 * * \\
(-2.538)\end{array}$ & $\begin{array}{c}-78.083 * * * \\
(-3.096)\end{array}$ & $\begin{array}{c}-15.031 * \\
(-1.954)\end{array}$ & $\begin{array}{c}-94.661 * * \\
(-2.412)\end{array}$ & $\begin{array}{l}-87.942 \\
(-1.407)\end{array}$ \\
\hline Geodiv & $\begin{array}{c}-70.265 * * \\
(-2.387) \\
\end{array}$ & $\begin{array}{c}2.667 \\
(0.089) \\
\end{array}$ & $\begin{array}{l}-16.284 \\
(-0.480)\end{array}$ & $\begin{array}{c}-1.647 \\
(-0.034) \\
\end{array}$ & $\begin{array}{c}-134.927 * * \\
(-2.306)\end{array}$ \\
\hline Invest & $\begin{array}{l}44.680 \\
(1.528) \\
\end{array}$ & $\begin{array}{c}6.151 \\
(0.287) \\
\end{array}$ & $\begin{array}{c}5.245 \\
(1.011) \\
\end{array}$ & $\begin{array}{c}-0.498 \\
(-0.013) \\
\end{array}$ & $\begin{array}{l}77.744 \\
(0.993) \\
\end{array}$ \\
\hline GDP & $\begin{array}{c}-0.084 \\
(-0.022)\end{array}$ & $\begin{array}{c}2.798 \\
(0.990) \\
\end{array}$ & $\begin{array}{c}0.036 \\
(0.071)\end{array}$ & $\begin{array}{c}5.021 \\
(0.847) \\
\end{array}$ & $\begin{array}{c}-3.097 \\
(-0.355)\end{array}$ \\
\hline Interest & $\begin{array}{c}-2.745 \\
(-0.611) \\
\end{array}$ & $\begin{array}{c}2.069 \\
(0.599) \\
\end{array}$ & $\begin{array}{c}-0.401 \\
(-0.659) \\
\end{array}$ & $\begin{array}{c}6.828 \\
(0.914) \\
\end{array}$ & $\begin{array}{c}-8.441 \\
(-0.830) \\
\end{array}$ \\
\hline Constant & $\begin{array}{c}-139.510 \\
(-1.574)\end{array}$ & $\begin{array}{c}-7.210 \\
(-0.111)\end{array}$ & $\begin{array}{l}-14.112 \\
(-0.448)\end{array}$ & $\begin{array}{l}-92.191 \\
(-0.706)\end{array}$ & $\begin{array}{c}-510.204 * * \\
(-2.313)\end{array}$ \\
\hline Sample size & 318 & 203 & 110 & 93 & 115 \\
\hline
\end{tabular}

Note. (1) $* * *$ means $p<0.01, * *$ means $p<0.05$, and $*$ means $p<0.1$. (2) Below the estimated coefficient () is a robust standard error.

regression results of Chinese-funded and foreign-funded $\mathrm{P} / \mathrm{L}$ insurance companies. Columns (3) and (4) in the table, respectively, show the regression results of large and small Chinese-funded P/L insurance companies.

In the regression results of the whole sample, the proportion of nonauto insurance business is significantly positively correlated with solvency at $1 \%$ level; that is, increasing the proportion of nonauto insurance business can improve the solvency of $\mathrm{P} / \mathrm{L}$ insurance companies. As for the Chinese-funded $\mathrm{P} / \mathrm{L}$ insurance companies, the proportion of nonauto insurance business is significantly positively correlated with solvency at $1 \%$, indicating that the increase of the proportion of nonauto insurance business in the business structure will significantly enhance their solvency. The regression results of foreignfunded $\mathrm{P} / \mathrm{L}$ insurance companies also show that the proportion of nonauto insurance business is significantly positively correlated with their solvency at $1 \%$; that is, more concentrated business structure of foreign-funded P/ $\mathrm{L}$ insurance companies in nonauto insurance business can enhance their solvency.

Columns (3) and (4) in Table 3 show the regression results of large and small Chinese-funded $\mathrm{P} / \mathrm{L}$ insurance companies. In the regression results of large Chinese-funded $\mathrm{P} / \mathrm{L}$ insurance companies, the proportion of nonauto insurance business is not significantly correlated with their solvency; that is, the change of business structure has no significant impact on their solvency. As for small Chinesefunded $\mathrm{P} / \mathrm{L}$ insurance companies, the regression results show that the proportion of nonauto insurance business is significantly positively correlated with their solvency at $1 \%$; that is, increasing the proportion of nonauto insurance business and reducing the concentration of the business structure of small Chinese companies can significantly enhance their solvency.

\subsection{Mediating Effect Test of Profitability and Reinsurance Behavior Based on the Stepwise Regression Method}

4.3.1. The Mediating Effect of Profitability. The above basic regression results show that the regression coefficient $\alpha_{1}$ is significant only for small Chinese-funded $\mathrm{P} / \mathrm{L}$ insurance companies and foreign-funded $\mathrm{P} / \mathrm{L}$ insurance companies, but not for large Chinese-funded $\mathrm{P} / \mathrm{L}$ insurance companies. Therefore, according to the testing process of mediating effect, this section only needs to test the mediating effect of the above two samples based on models (2) and (3).

Table 4 reports the mediating effect test results of small Chinese-funded and foreign-funded P/L insurance companies, respectively. Columns (1) and (2) in Table 4 are the panel fixed effect regression results of the mediating effect model for small Chinese-funded companies. The proportion of nonauto insurance business has no significant positive impact on profitability of small Chinese-funded companies. After controlling for the effect of nonauto insurance business proportion on solvency, the coefficients of profitability are positive, but not significant. Therefore, the mediating effect of profitability of small Chinese-funded companies is not significant, which does not support theoretical Hypothesis 1. This may be because small Chinese-funded $\mathrm{P} / \mathrm{L}$ insurance companies have developed nonauto insurance businesses in the short term, which, due to the limited scale of nonauto insurance businesses, have not played the synergistic effect of improving profitability. In addition, in the early stage, the expansion of new businesses requires a lot of upfront costs, 
TABLE 4: Mediating effect test of profitability based on the stepwise regression method.

\begin{tabular}{|c|c|c|c|c|}
\hline \multirow[b]{2}{*}{ Variables } & \multicolumn{2}{|c|}{ Small Chinese-funded } & \multicolumn{2}{|c|}{ Foreign-funded } \\
\hline & $\begin{array}{c}\text { Roa } \\
(1)\end{array}$ & $\begin{array}{l}\text { Solvency } \\
\text { (2) }\end{array}$ & $\begin{array}{c}\text { Roa } \\
(3)\end{array}$ & $\begin{array}{l}\text { Solvency } \\
\text { (4) }\end{array}$ \\
\hline Roa & & $\begin{array}{l}121.422 \\
(0.684)\end{array}$ & & $\begin{array}{c}175.666 \\
(1.171)\end{array}$ \\
\hline Nonauto & $\begin{array}{c}0.004 \\
(0.101) \\
\end{array}$ & $\begin{array}{c}160.285 * * * \\
(3.908)\end{array}$ & $\begin{array}{r}0.067 * \\
(1.701)\end{array}$ & $\begin{array}{c}269.925 * * * \\
(4.022)\end{array}$ \\
\hline Size & $\begin{array}{c}0.094 * * * \\
(7.469)\end{array}$ & $\begin{array}{c}0.044 \\
(0.002)\end{array}$ & $\begin{array}{c}0.053 * * * \\
(4.563)\end{array}$ & $\begin{array}{c}50.830 * \\
(1.936)\end{array}$ \\
\hline Loss & $\begin{array}{r}0.062 * \\
(1.691) \\
\end{array}$ & $\begin{array}{c}-92.206 * * \\
(-2.327) \\
\end{array}$ & $\begin{array}{r}-0.015 * \\
(-1.961) \\
\end{array}$ & $\begin{array}{c}3.051 \\
(0.262)\end{array}$ \\
\hline Lev & $\begin{array}{c}-0.047 \\
(-1.352)\end{array}$ & $\begin{array}{c}-92.620 * * \\
(-2.343)\end{array}$ & $\begin{array}{c}-0.120 * * * \\
(-3.593)\end{array}$ & $\begin{array}{l}-65.867 \\
(-1.011)\end{array}$ \\
\hline Geodiv & $\begin{array}{r}-0.073 * \\
(-1.738) \\
\end{array}$ & $\begin{array}{c}4.206 \\
(0.085) \\
\end{array}$ & $\begin{array}{c}0.031 \\
(0.977) \\
\end{array}$ & $\begin{array}{c}-131.055 * * \\
(-2.241) \\
\end{array}$ \\
\hline Invest & $\begin{array}{c}0.049 \\
(1.483)\end{array}$ & $\begin{array}{c}-6.124 \\
(-0.153)\end{array}$ & $\begin{array}{c}0.046 \\
(1.157)\end{array}$ & $\begin{array}{l}71.231 \\
(0.909)\end{array}$ \\
\hline GDP & $\begin{array}{c}-0.000 \\
(-0.063)\end{array}$ & $\begin{array}{c}4.761 \\
(0.798) \\
\end{array}$ & $\begin{array}{c}0.005 \\
(0.842) \\
\end{array}$ & $\begin{array}{c}-4.059 \\
(-0.464)\end{array}$ \\
\hline Interest & $\begin{array}{l}-0.012 * \\
(-1.723)\end{array}$ & $\begin{array}{c}8.173 \\
(1.054) \\
\end{array}$ & $\begin{array}{c}-0.004 \\
(-0.643)\end{array}$ & $\begin{array}{c}-7.559 \\
(-0.742)\end{array}$ \\
\hline Constant & $\begin{array}{c}-0.691 * * * \\
(-5.795)\end{array}$ & $\begin{array}{l}-22.829 \\
(-0.138)\end{array}$ & $\begin{array}{c}-0.459 * * * \\
(-4.375)\end{array}$ & $\begin{array}{c}-416.230 * \\
(-1.776)\end{array}$ \\
\hline Sample size & 104 & 93 & 155 & 115 \\
\hline
\end{tabular}

Note. (1) $* * *$ means $p<0.01, * *$ means $p<0.05$, and $*$ means $p<0.1$. (2) Below the estimated coefficient () is a robust standard error.

including manpower and infrastructure investment. Therefore, the effect of improving profitability is not achieved in the short term.

Columns (3) and (4) in Table 4, respectively, show the regression results of foreign-funded $\mathrm{P} / \mathrm{L}$ insurance companies. The results show that the coefficient of nonauto insurance business ratio of foreign-funded $\mathrm{P} / \mathrm{L}$ insurance companies is significantly positive at the level of $10 \%$; that is, the increase of nonauto insurance business ratio can significantly enhance their profitability. After controlling the influence of the nonauto insurance business ratio to solvency, the coefficient of profitability is positive, but not significant. Although the auto insurance business has an adverse impact on profitability, the foreign-funded $\mathrm{P} / \mathrm{L}$ insurance companies have not let this negative effect to further weaken their solvency. This conclusion does not support theoretical Hypothesis 1 either. As for foreignfunded $\mathrm{P} / \mathrm{L}$ companies, because of their lack of market experience and data accumulation in China's auto insurance business and their marketing network layout is difficult to develop in a short period of time, the increase of the proportion of auto insurance business does not bring profit growth. Instead, the increase in input costs and compensation expenses leads to a decline in profitability.

4.3.2. The Mediating Effect of Reinsurance Behavior. As shown in the previous research conclusions, only the regression $\alpha_{1}$ of small Chinese-funded and foreign-funded $\mathrm{P} / \mathrm{L}$ insurance companies is significant in the regression results of model (1). This section also only needs to conduct the following intermediary effect test of the above two samples.

Table 5 shows the regression results of the mediating effect of reinsurance behavior. The empirical results show that the nonauto insurance business ratio to the reinsurance rate of small Chinese-funded companies is significantly positive at $5 \%$, indicating that when the proportion of nonauto insurance business is relatively high, the diversification of the business structure will increase, and small Chinese-funded companies will tend to buy more reinsurance to transfer risks. This is because the source and carrier of risks in nonauto insurance business are more complex than those in auto insurance business, and some risks may even bring huge compensation liability once they occur. With limited capital strength, small Chinese-funded companies are more inclined to transfer risks by means of reinsurance when the nonauto insurance business income increases. The regression results of column (2) in Table 5 show that the impact of reinsurance on their solvency is significantly positive at $1 \%$, so the mediating effect of reinsurance behavior does exist, which supports theoretical Hypothesis 2.

From the empirical results in columns (3) and (4) of Table 5, the nonauto insurance business ratio to the reinsurance ratio of foreign-funded $\mathrm{P} / \mathrm{L}$ insurance companies is significantly positive at $1 \%$, indicating that when the nonauto insurance business accounts for a relatively high proportion, foreign-funded $\mathrm{P} / \mathrm{L}$ insurance companies will increase their reinsurance ratio. When the proportion of nonauto insurance business increases, foreign-funded $\mathrm{P} / \mathrm{L}$ 
TABLE 5: Mediating effect test of reinsurance based on the stepwise regression method.

\begin{tabular}{|c|c|c|c|c|}
\hline \multirow[b]{2}{*}{ Variables } & \multicolumn{2}{|c|}{ Small Chinese-funded } & \multicolumn{2}{|c|}{ Foreign-funded } \\
\hline & $\begin{array}{c}\text { Rein } \\
(1)\end{array}$ & $\begin{array}{c}\text { Solvency } \\
(2)\end{array}$ & $\begin{array}{c}\text { Rein } \\
(3)\end{array}$ & $\begin{array}{c}\text { Solvency } \\
(4)\end{array}$ \\
\hline Rein & & $\begin{array}{c}303.340 * * * \\
(5.950)\end{array}$ & & $\begin{array}{c}287.030 * * * \\
(3.135)\end{array}$ \\
\hline Nonauto & $\begin{array}{c}0.181 * * \\
(2.279) \\
\end{array}$ & $\begin{array}{c}107.043 * * * \\
(3.126)\end{array}$ & $\begin{array}{c}0.373 * * * \\
(5.547)\end{array}$ & $\begin{array}{c}166.836 * * \\
(2.285)\end{array}$ \\
\hline Size & $\begin{array}{c}-0.005 \\
(-0.208)\end{array}$ & $\begin{array}{r}12.104 \\
(0.990) \\
\end{array}$ & $\begin{array}{c}-0.010 \\
(-0.482)\end{array}$ & $\begin{array}{c}54.491 * * \\
(2.349)\end{array}$ \\
\hline Loss & $\begin{array}{c}-0.110 \\
(-1.520) \\
\end{array}$ & $\begin{array}{l}-46.726 \\
(-1.425) \\
\end{array}$ & $\begin{array}{c}0.020 \\
(1.594) \\
\end{array}$ & $\begin{array}{c}-6.465 \\
(-0.583)\end{array}$ \\
\hline Lev & $\begin{array}{l}-0.042 \\
(-0.616) \\
\end{array}$ & $\begin{array}{c}-84.070 * * \\
(-2.645) \\
\end{array}$ & $\begin{array}{l}-0.068 \\
(-1.177)\end{array}$ & $\begin{array}{l}-67.155 \\
(-1.120)\end{array}$ \\
\hline Geodiv & $\begin{array}{c}0.106 \\
(1.283) \\
\end{array}$ & $\begin{array}{l}-30.085 \\
(-0.762) \\
\end{array}$ & $\begin{array}{c}-0.026 \\
(-0.476) \\
\end{array}$ & $\begin{array}{l}-94.173 \\
(-1.644) \\
\end{array}$ \\
\hline Invest & $\begin{array}{c}0.097 \\
(1.481) \\
\end{array}$ & $\begin{array}{l}-24.628 \\
(-0.776)\end{array}$ & $\begin{array}{c}-0.196 * * * \\
(-2.841)\end{array}$ & $\begin{array}{c}131.323 * \\
(1.713)\end{array}$ \\
\hline GDP & $\begin{array}{c}0.005 \\
(0.407) \\
\end{array}$ & $\begin{array}{c}3.009 \\
(0.626) \\
\end{array}$ & $\begin{array}{c}-0.002 \\
(-0.177) \\
\end{array}$ & $\begin{array}{c}-3.257 \\
(-0.391) \\
\end{array}$ \\
\hline Interest & $\begin{array}{l}-0.020 \\
(-1.384)\end{array}$ & $\begin{array}{c}13.547 * * \\
(2.204)\end{array}$ & $\begin{array}{c}-0.009 \\
(-0.858) \\
\end{array}$ & $\begin{array}{c}-9.605 \\
(-0.989) \\
\end{array}$ \\
\hline Constant & $\begin{array}{c}0.073 \\
(0.310) \\
\end{array}$ & $\begin{array}{c}-129.676 \\
(-1.226) \\
\end{array}$ & $\begin{array}{c}0.354 * \\
(1.968) \\
\end{array}$ & $\begin{array}{c}-516.865 * * \\
(-2.456) \\
\end{array}$ \\
\hline Sample size & 104 & 93 & 155 & 115 \\
\hline
\end{tabular}

Note. (1) *** means $p<0.01, * *$ means $p<0.05$, and $*$ means $p<0.1$. (2) Below the estimated coefficient () is a robust standard error.

insurance companies will increase the reinsurance ceding ratio in order to prevent excessive concentration of risks, which is consistent with the research conclusions of Curak et al. [21].

Further empirical test results show that the coefficient of reinsurance and solvency of foreign-funded $\mathrm{P} / \mathrm{L}$ insurance companies is significantly positive at $1 \%$ level, which further confirms that the intermediary effect of reinsurance behavior exists. This conclusion supports theoretical Hypothesis 2. Foreign-funded $\mathrm{P} / \mathrm{L}$ insurance companies pay great attention to the management of solvency. Although the newly developed auto insurance business has a negative impact on profitability, foreign-funded $\mathrm{P} / \mathrm{L}$ insurance companies can still avoid the negative impact of the decline in profitability on solvency by strengthening the reinsurance ceding management.

4.3.3. Multiple Mediating Effects of Profitability and Reinsurance Behavior Based on the Bootstrap Method. Although the stepwise regression method used above is one of the commonly used mediating effect testing methods, in recent years, scholars began to have positive and negative views on the stepwise regression method. Firstly, the stepwise regression method has the lowest testing force on the mediating effect among all the methods. In other words, it is difficult to test the significance of the mediating effect with the stepwise regression method, which is likely to cause inaccurate results. However, scholars who support the stepwise regression method believe that, on the contrary, if the results of stepwise regression have reached a significant level, the disadvantage of low test power is more likely to prove the existence of the mediating effect. Wen and Ye [34] pointed out that if the results of the stepwise regression method were significant, the results were better than other mediating effect testing methods. Secondly, the question of complete mediation and partial mediation: due to the influence of sample and total effect size, the results of the complete mediating effect obtained by the stepwise regression method are not accurate. Preacher and Hayes [35] pointed out that when the total effect value is small and the sample size is small, the result obtained is prone to a complete mediating effect, but the probability of the complete mediating effect in reality is very low. With the development of statistical and analysis software and the development of the mediating effect model, bootstrap method has become a new method to test the mediating effect.

Therefore, this paper uses Amos 21.0 to test the mediating effect and influence degree of the profitability and reinsurance behavior of $\mathrm{P} / \mathrm{L}$ insurance companies on the basis of stepwise regression. In this paper, the deviation correction percentile bootstrap method was used to conduct repeat sampling for 200 times and select 95\% confidence interval to test the mediating effect of profitability and reinsurance behavior.

Table 6 reports the results of the bootstrap test of multiple mediating effects for small Chinese-funded $\mathrm{P} / \mathrm{L}$ insurance companies. It can be seen from Table 6 that the path coefficient of nonauto insurance business proportion 
TABLE 6: Test results of the multiple mediating effect bootstrap method (small Chinese-funded companies).

\begin{tabular}{|c|c|c|c|c|}
\hline & Effect value & $p$ value & BootCI floor & BootCI ceiling \\
\hline Nonauto $\longrightarrow$ roa & 0.028 & 0.073 & 0.001 & 0.062 \\
\hline Roa- $\longrightarrow$ solvency & 134.145 & 0.516 & -187.747 & 453.438 \\
\hline Nonauto $\longrightarrow$ rein & 0.293 & 0.013 & 0.138 & 0.426 \\
\hline Rein $\longrightarrow$ solvency & 177.770 & 0.055 & 63.832 & 274.988 \\
\hline Nonauto $\longrightarrow$ solvency (direct effect) & 50.832 & 0.052 & 7.077 & 122.259 \\
\hline Nonauto $\longrightarrow$ solvency (indirect effect) & 55.875 & 0.017 & 14.503 & 100.759 \\
\hline Nonauto $\longrightarrow$ solvency (total effect) & 106.706 & 0.007 & 36.008 & 204.508 \\
\hline
\end{tabular}

affecting profitability is 0.028 , which is significant at $10 \%$ level, but the path coefficient of profitability affecting solvency is not significant. Therefore, the mediating effect of profitability is not significant.

From the perspective of the path of "business structurereinsurance behavior-solvency," the path coefficient of the business structure influencing reinsurance behavior is 0.293 , which is significant at the level of 5\%. The path coefficient of reinsurance affecting solvency is 177.770 . The results in Table 6 also show that the mediating effect value of reinsurance is 55.875 , which is significant at the level of $5 \%$. The direct effect value of the business structure on solvency is 50.832. Based on the above analysis, it can be seen that the mediating effect of profitability is not significant, and the mediating effect of reinsurance is significant, which is a partial mediating effect and accounts for $52.36 \%$ of the total effect.

Table 7 reports the test results of the bootstrap method of multiple mediating effects for foreign-funded $\mathrm{P} / \mathrm{L}$ insurance companies. The results in Table 7 show that the path coefficient of the business structure affecting profitability is 0.175 , with a significance level of $10 \%$, while the path coefficient of profitability affecting solvency is not significant.

From the perspective of reinsurance behavior, the path coefficient of the business structure affecting solvency is 0.384 at $1 \%$, and the path coefficient of reinsurance ratio affecting solvency is 150.306 at $1 \%$. In addition, the mediating effect value of reinsurance is 53.127 , with a significance level of $1 \%$. The direct effect of the business structure on solvency is not significant. To sum up, the mediating effect of profitability is not significant, while the mediating effect of reinsurance is significant and complete.

Table 8 reports the test results of the bootstrap method with multiple mediating effects for large Chinese-funded P/L insurance companies. As shown in Table 8, the total effect of the business structure on solvency is not significant, and the direct effect of the business structure on solvency is not significant either. In addition, the $p$ value of the mediating effect of the business structure on solvency is 0.614 . Therefore, neither profitability nor reinsurance behavior has a significant mediating effect for large Chinese-funded P/L insurance companies.

\section{Robustness Test}

5.1. Robustness Test of "Heteroscedasticity-Sequence Correlation-Cross-Section Correlation". Driscoll and Kraay [36] proposed that the panel data may have problems of cross-section correlation and heteroscedasticity. To solve the above problems, this paper adopted the method proposed by Hoechle [37] to conduct robustness test on the previous empirical model.

Table 9 reports the robustness test result of the impact of the business structure on solvency, and its conclusion is consistent with the above. The increase in the proportion of nonauto insurance business can significantly enhance the solvency of the small Chinese-funded $\mathrm{P} / \mathrm{L}$ and foreignfunded $\mathrm{P} / \mathrm{L}$ insurance companies.

Tables 10 and 11, respectively, report the robustness test results of the mediating effect of the profitability and reinsurance behavior. The results show that the increase in the proportion of nonauto insurance business of small Chinese-funded companies cannot improve their solvency by affecting their profitability, and the positive impact of the business structure of small Chinese-funded companies on their solvency is realized through the reinsurance channel. The mediating effect of profitability does not exist for foreign-funded $\mathrm{P} / \mathrm{L}$ insurance companies either. The increase in the proportion of nonauto insurance businesses will increase their reinsurance rate and thus enhance their solvency, which is consistent with the previous conclusions.

5.2. Endogeneity Test. In order to test the robustness of the model, the instrumental variable method is further used in this paper. In this paper, the one-phase lag (L. nonauto) of the business structure was used as the instrumental variable to carry out the two-stage generalized moment estimation. Table 12 shows the endogenous test of the impact of the business structure on solvency. The conclusions are consistent with the previous conclusions. Small Chinese-funded and foreign-funded $\mathrm{P} / \mathrm{L}$ insurance companies can significantly enhance their solvency by increasing the proportion of nonauto insurance business.

Tables 13 and 14, respectively, show the endogeneity test results of the mediating effect of the profitability and reinsurance behavior. The increase in the proportion of nonauto insurance business of small Chinese-funded P/L insurance companies cannot significantly improve their profitability and thus affect their solvency, but it can significantly increase their reinsurance rate and thus enhance their solvency.

For foreign-funded P/L insurance companies, the impact of the business structure on their solvency still exists through increasing the reinsurance rate, and the intermediary channel of profitability does not exist. The 
TABLe 7: Test results of the multiple mediating effect bootstrap method (foreign-funded companies).

\begin{tabular}{lcccc}
\hline & Effect value & $p$ value & BootCI floor & BootCI ceiling \\
\hline Nonauto $\longrightarrow$ roa & 0.175 & 0.026 & 0.138 & 0.205 \\
Roa $\longrightarrow$ solvency & -26.147 & 0.587 & -219.477 & 53.473 \\
Nonauto $\longrightarrow$ rein & 0.384 & 0.006 & 0.321 & 0.461 \\
Rein $\longrightarrow$ solvency & 150.306 & 0.005 & 26.757 & 329.816 \\
Nonauto $\longrightarrow$ solvency (direct effect) & -4.064 & 0.776 & -44.945 & 16.516 \\
Nonauto $\longrightarrow$ solvency (indirect effect) & 53.127 & 0.004 & 17.376 & 120.390 \\
Nonauto $\longrightarrow$ solvency (total effect) & 49.063 & 0.002 & 22.316 & 126.871 \\
\hline
\end{tabular}

TABLe 8: Test results of the multiple mediating effect bootstrap method (large Chinese-funded companies).

\begin{tabular}{lcccc}
\hline & Effect value & $p$ value & BootCI floor & BootCI ceiling \\
\hline Nonauto $\longrightarrow$ roa & 0.029 & 0.010 & 0.013 & 0.049 \\
Roa $\longrightarrow$ solvency & 32.230 & 0.771 & -30.190 & 107.613 \\
Nonauto $\longrightarrow$ rein & 0.186 & 0.019 & 0.120 & 0.266 \\
Rein $\longrightarrow$ solvency & -11.631 & 0.030 & -25.495 & -3.908 \\
Nonauto $\longrightarrow$ solvency (direct effect) & 0.302 & 0.955 & -8.862 & 5.837 \\
Nonauto $\longrightarrow$ solvency (indirect effect) & -1.230 & 0.614 & -3.238 & 2.234 \\
Nonauto $\longrightarrow$ solvency (total effect) & -0.928 & 0.746 & -7.821 & 3.970 \\
\hline
\end{tabular}

TABLE 9: Robustness test of the impact of the business structure on solvency.

\begin{tabular}{|c|c|c|c|c|c|}
\hline Variables & $\begin{array}{l}\text { Full sample } \\
\text { (1) }\end{array}$ & $\begin{array}{c}\text { Chinese-funded } \\
\text { (2) }\end{array}$ & $\begin{array}{l}\text { Large Chinese-funded } \\
\text { (3) }\end{array}$ & $\begin{array}{l}\text { Small Chinese-funded } \\
\text { (4) }\end{array}$ & $\begin{array}{l}\text { Foreign-funded } \\
\text { (5) }\end{array}$ \\
\hline Nonauto & $\begin{array}{c}182.025 * * \\
(3.103) \\
\end{array}$ & $\begin{array}{c}126.532 * * * \\
(6.068)\end{array}$ & $\begin{array}{c}0.866 \\
(0.057) \\
\end{array}$ & $\begin{array}{c}160.839 * * * \\
(6.025)\end{array}$ & $\begin{array}{c}278.471 * \\
(2.237) \\
\end{array}$ \\
\hline Size & $\begin{array}{l}18.535 \\
(1.789) \\
\end{array}$ & $\begin{array}{c}1.793 \\
(0.432) \\
\end{array}$ & $\begin{array}{c}4.471 * * \\
(3.690) \\
\end{array}$ & $\begin{array}{c}8.991 \\
(0.727) \\
\end{array}$ & $\begin{array}{c}62.998 * * \\
(2.685) \\
\end{array}$ \\
\hline Loss & $\begin{array}{c}0.149 \\
(0.025) \\
\end{array}$ & $\begin{array}{c}-60.020 * * * \\
(-5.125)\end{array}$ & $\begin{array}{c}-3.999 \\
(-0.838)\end{array}$ & $\begin{array}{c}-91.854 * * \\
(-3.195) \\
\end{array}$ & $\begin{array}{c}0.087 \\
(0.011) \\
\end{array}$ \\
\hline Lev & $\begin{array}{c}-73.310 * * * \\
(-3.769)\end{array}$ & $\begin{array}{c}-78.083 * * \\
(-2.817)\end{array}$ & $\begin{array}{c}-15.031 * \\
(-1.943)\end{array}$ & $\begin{array}{c}-94.661 * * * \\
(-4.471)\end{array}$ & $\begin{array}{l}-87.942 \\
(-1.857) \\
\end{array}$ \\
\hline Geodiv & $\begin{array}{c}-70.265 * * * \\
(-4.010)\end{array}$ & $\begin{array}{c}2.667 \\
(0.185) \\
\end{array}$ & $\begin{array}{l}-16.284 \\
(-0.517)\end{array}$ & $\begin{array}{c}-1.647 \\
(-0.087) \\
\end{array}$ & $\begin{array}{c}-134.927 * * * \\
(-3.966)\end{array}$ \\
\hline Invest & $\begin{array}{r}44.680 \\
(1.280) \\
\end{array}$ & $\begin{array}{c}6.151 \\
(0.415) \\
\end{array}$ & $\begin{array}{c}5.245 \\
(1.830) \\
\end{array}$ & $\begin{array}{c}-0.498 \\
(-0.019) \\
\end{array}$ & $\begin{array}{l}77.744 \\
(1.242) \\
\end{array}$ \\
\hline GDP & $\begin{array}{c}-0.084 \\
(-0.067) \\
\end{array}$ & $\begin{array}{c}2.798 * * * \\
(5.654) \\
\end{array}$ & $\begin{array}{c}0.036 \\
(0.157) \\
\end{array}$ & $\begin{array}{c}5.021 * * * \\
(4.128)\end{array}$ & $\begin{array}{c}-3.097 \\
(-0.687) \\
\end{array}$ \\
\hline Interest & $\begin{array}{c}-2.745 \\
(-0.928) \\
\end{array}$ & $\begin{array}{c}2.069 \\
(1.470) \\
\end{array}$ & $\begin{array}{c}-0.401 \\
(-0.750) \\
\end{array}$ & $\begin{array}{c}6.828 * * \\
(3.606) \\
\end{array}$ & $\begin{array}{c}-8.441 \\
(-0.969) \\
\end{array}$ \\
\hline Constant & $\begin{array}{c}-139.510 \\
(-1.174)\end{array}$ & $\begin{array}{c}-7.210 \\
(-0.139)\end{array}$ & $\begin{array}{l}-14.112 \\
(-0.472)\end{array}$ & $\begin{array}{l}-92.191 \\
(-0.989) \\
\end{array}$ & $\begin{array}{c}-510.204 \\
(-1.752)\end{array}$ \\
\hline Sample size & 318 & 203 & 110 & 93 & 115 \\
\hline
\end{tabular}

Note. (1) $* * *$ means $p<0.01, * *$ means $p<0.05$, and $*$ means $p<0.1$. (2) Below the estimated coefficient () is a robust standard error.

TABLE 10: Robustness test of the mediating effect of profitability.

\begin{tabular}{|c|c|c|c|c|}
\hline \multirow[b]{2}{*}{ Variables } & \multicolumn{2}{|c|}{ Small Chinese-funded } & \multicolumn{2}{|c|}{ Foreign-funded } \\
\hline & $\begin{array}{l}\text { Roa } \\
(1)\end{array}$ & $\begin{array}{l}\text { Solvency } \\
\text { (2) }\end{array}$ & $\begin{array}{l}\text { Roa } \\
\text { (3) }\end{array}$ & $\begin{array}{c}\text { Solvency } \\
\text { (4) }\end{array}$ \\
\hline Roa & & $\begin{array}{l}121.422 \\
(0.629)\end{array}$ & & $\begin{array}{c}175.666 \\
(1.930)\end{array}$ \\
\hline Nonauto & $\begin{array}{c}0.004 \\
(0.334)\end{array}$ & $\begin{array}{c}160.285 * * * \\
(6.300)\end{array}$ & $\begin{array}{c}0.067 * \\
(1.905)\end{array}$ & $\begin{array}{c}269.925 * \\
(2.311)\end{array}$ \\
\hline Size & $\begin{array}{c}0.094 * * * \\
(8.122)\end{array}$ & $\begin{array}{c}0.044 \\
(0.002)\end{array}$ & $\begin{array}{c}0.053 * * * \\
(13.306)\end{array}$ & $\begin{array}{c}50.830 * * \\
(2.809)\end{array}$ \\
\hline
\end{tabular}


Table 10: Continued.

\begin{tabular}{|c|c|c|c|c|}
\hline \multirow[b]{2}{*}{ Variables } & \multicolumn{2}{|c|}{ Small Chinese-funded } & \multicolumn{2}{|c|}{ Foreign-funded } \\
\hline & $\begin{array}{l}\text { Roa } \\
(1)\end{array}$ & $\begin{array}{l}\text { Solvency } \\
\text { (2) }\end{array}$ & $\begin{array}{l}\text { Roa } \\
(3)\end{array}$ & $\begin{array}{l}\text { Solvency } \\
\text { (4) }\end{array}$ \\
\hline Loss & $\begin{array}{c}0.062 \\
(1.335) \\
\end{array}$ & $\begin{array}{c}-92.206 * * \\
(-3.024)\end{array}$ & $\begin{array}{c}-0.015 * * \\
(-2.915) \\
\end{array}$ & $\begin{array}{c}3.051 \\
(0.446) \\
\end{array}$ \\
\hline Lev & $\begin{array}{r}-0.047 * \\
(-1.975) \\
\end{array}$ & $\begin{array}{c}-92.620 * * * \\
(-5.693)\end{array}$ & $\begin{array}{c}-0.120 * * * \\
(-9.098)\end{array}$ & $\begin{array}{l}-65.867 \\
(-1.261) \\
\end{array}$ \\
\hline Geodiv & $\begin{array}{c}-0.073 * * \\
(-3.015) \\
\end{array}$ & $\begin{array}{c}4.206 \\
(0.195) \\
\end{array}$ & $\begin{array}{c}0.031 \\
(1.221) \\
\end{array}$ & $\begin{array}{c}-131.055 * * * * \\
(-4.449)\end{array}$ \\
\hline Invest & $\begin{array}{c}0.049 * * * \\
(3.772)\end{array}$ & $\begin{array}{c}-6.124 \\
(-0.172)\end{array}$ & $\begin{array}{c}0.046 \\
(1.824)\end{array}$ & $\begin{array}{l}71.231 \\
(1.151)\end{array}$ \\
\hline GDP & $\begin{array}{c}-0.000 \\
(-0.161) \\
\end{array}$ & $\begin{array}{c}4.761 * * * \\
(4.440)\end{array}$ & $\begin{array}{c}0.005 * * \\
(3.473) \\
\end{array}$ & $\begin{array}{c}-4.059 \\
(-0.979) \\
\end{array}$ \\
\hline Interest & $\begin{array}{c}-0.012 \\
(-1.586) \\
\end{array}$ & $\begin{array}{l}8.173 * \\
(1.956) \\
\end{array}$ & $\begin{array}{c}-0.004 * * \\
(-2.945) \\
\end{array}$ & $\begin{array}{c}-7.559 \\
(-0.892) \\
\end{array}$ \\
\hline Constant & $\begin{array}{c}-0.691 * * * \\
(-10.439)\end{array}$ & $\begin{array}{l}-22.829 \\
(-0.146) \\
\end{array}$ & $\begin{array}{c}-0.459 * * * \\
(-9.258)\end{array}$ & $\begin{array}{c}-416.230 \\
(-1.727) \\
\end{array}$ \\
\hline Sample size & 104 & 93 & 155 & 115 \\
\hline
\end{tabular}

Note. (1) $* * *$ means $p<0.01, * *$ means $p<0.05$, and $*$ means $p<0.1$. (2) Below the estimated coefficient () is a robust standard error.

TABLE 11: The robustness test of the mediating effect of reinsurance behavior.

\begin{tabular}{|c|c|c|c|c|}
\hline \multirow[b]{2}{*}{ Variables } & \multicolumn{2}{|c|}{ Small Chinese-funded } & \multicolumn{2}{|c|}{ Foreign-funded } \\
\hline & $\begin{array}{c}\text { Rein } \\
(1)\end{array}$ & $\begin{array}{c}\text { Solvency } \\
(2)\end{array}$ & $\begin{array}{c}\text { Rein } \\
(3)\end{array}$ & $\begin{array}{c}\text { Solvency } \\
(4)\end{array}$ \\
\hline Rein & & $\begin{array}{c}303.340 * * * \\
(9.093)\end{array}$ & & $\begin{array}{c}287.030 * * \\
(2.455)\end{array}$ \\
\hline Nonauto & $\begin{array}{c}0.181 * * \\
(2.822) \\
\end{array}$ & $\begin{array}{c}107.043 * * * \\
(4.723)\end{array}$ & $\begin{array}{c}0.373 * * * \\
(4.787)\end{array}$ & $\begin{array}{c}166.836 * \\
(2.350)\end{array}$ \\
\hline Size & $\begin{array}{c}-0.005 \\
(-0.413)\end{array}$ & $\begin{array}{c}12.104 * \\
(1.970)\end{array}$ & $\begin{array}{l}-0.010 \\
(-0.909)\end{array}$ & $\begin{array}{c}54.491 * * \\
(3.338)\end{array}$ \\
\hline Loss & $\begin{array}{c}-0.110 \\
(-1.471) \\
\end{array}$ & $\begin{array}{c}-46.726 * \\
(-1.959) \\
\end{array}$ & $\begin{array}{c}0.020 * * * \\
(4.191)\end{array}$ & $\begin{array}{c}-6.465 \\
(-0.689) \\
\end{array}$ \\
\hline Lev & $\begin{array}{c}-0.042 \\
(-1.246) \\
\end{array}$ & $\begin{array}{c}-84.070 * * * \\
(-5.609)\end{array}$ & $\begin{array}{c}-0.068 \\
(-1.481) \\
\end{array}$ & $\begin{array}{l}-67.155 \\
(-1.602) \\
\end{array}$ \\
\hline Geodiv & $\begin{array}{c}0.106 * \\
(2.114)\end{array}$ & $\begin{array}{l}-30.085 \\
(-1.036)\end{array}$ & $\begin{array}{c}-0.026 \\
(-0.654)\end{array}$ & $\begin{array}{c}-94.173 * * * \\
(-4.316)\end{array}$ \\
\hline Invest & $\begin{array}{c}0.097 * * \\
(3.489) \\
\end{array}$ & $\begin{array}{l}-24.628 \\
(-1.286) \\
\end{array}$ & $\begin{array}{c}-0.196 * * \\
(-3.362) \\
\end{array}$ & $\begin{array}{c}131.323 * \\
(1.968) \\
\end{array}$ \\
\hline GDP & $\begin{array}{c}0.005 \\
(0.732) \\
\end{array}$ & $\begin{array}{c}3.009 * * * \\
(4.598)\end{array}$ & $\begin{array}{c}-0.002 \\
(-0.476)\end{array}$ & $\begin{array}{c}-3.257 \\
(-0.904)\end{array}$ \\
\hline Interest & $\begin{array}{c}-0.020 * * \\
(-2.835) \\
\end{array}$ & $\begin{array}{c}13.547 * * * \\
(7.028)\end{array}$ & $\begin{array}{c}-0.009 \\
(-1.363) \\
\end{array}$ & $\begin{array}{c}-9.605 \\
(-1.335) \\
\end{array}$ \\
\hline Constant & $\begin{array}{c}0.073 \\
(0.837) \\
\end{array}$ & $\begin{array}{c}-129.676 * * \\
(-2.916)\end{array}$ & $\begin{array}{c}0.354 * * \\
(3.486)\end{array}$ & $\begin{array}{c}-516.865 * \\
(-2.092) \\
\end{array}$ \\
\hline Sample size & 104 & 93 & 155 & 115 \\
\hline
\end{tabular}

Note. (1) $* * *$ means $p<0.01, * *$ means $p<0.05$, and $*$ means $p<0.1$. (2) Below the estimated coefficient () is a robust standard error.

TABLE 12: The endogeneity test of the impact of the business structure on solvency.

\begin{tabular}{|c|c|c|c|c|c|}
\hline Variables & $\begin{array}{l}\text { Full sample } \\
\text { (1) }\end{array}$ & $\begin{array}{c}\text { Chinese-funded } \\
\text { (2) }\end{array}$ & $\begin{array}{l}\text { Large Chinese-funded } \\
\text { (3) }\end{array}$ & $\begin{array}{l}\text { Small Chinese-funded } \\
(4)\end{array}$ & $\begin{array}{l}\text { Foreign-funded } \\
\text { (5) }\end{array}$ \\
\hline Nonauto & $\begin{array}{c}8.498 * * * \\
(4.384)\end{array}$ & $\begin{array}{c}4.680 \\
(1.500)\end{array}$ & $\begin{array}{l}1.315 \\
(0.423)\end{array}$ & $\begin{array}{c}11.401 * * \\
(2.113)\end{array}$ & $\begin{array}{c}7.151 * * \\
(2.077)\end{array}$ \\
\hline Size & $\begin{array}{c}1.208 * * \\
(2.290)\end{array}$ & $\begin{array}{l}1.045 * \\
(1.946)\end{array}$ & $\begin{array}{l}1.127 \\
(1.333)\end{array}$ & $\begin{array}{l}-0.765 \\
(-1.022)\end{array}$ & $\begin{array}{l}-2.773 \\
(-1.459)\end{array}$ \\
\hline
\end{tabular}


Table 12: Continued.

\begin{tabular}{|c|c|c|c|c|c|}
\hline Variables & $\begin{array}{c}\text { Full sample } \\
(1)\end{array}$ & $\begin{array}{c}\text { Chinese-funded } \\
(2)\end{array}$ & $\begin{array}{l}\text { Large Chinese-funded } \\
\text { (3) }\end{array}$ & $\begin{array}{l}\text { Small Chinese-funded } \\
(4)\end{array}$ & $\begin{array}{c}\text { Foreign-funded } \\
(5)\end{array}$ \\
\hline Loss & $\begin{array}{r}2.265 * * \\
(2.420)\end{array}$ & $\begin{array}{l}-4.897 * \\
(-1.675)\end{array}$ & $\begin{array}{l}-4.718 \\
(-1.281)\end{array}$ & $\begin{array}{c}-3.349 \\
(-0.940)\end{array}$ & $\begin{array}{c}2.307 * * \\
(2.217)\end{array}$ \\
\hline Lev & $\begin{array}{c}-36.804 * * * \\
(-8.976)\end{array}$ & $\begin{array}{c}-25.562 * * * \\
(-7.280)\end{array}$ & $\begin{array}{r}-13.810 * \\
(-1.870)\end{array}$ & $\begin{array}{c}-28.709 * * * \\
(-7.580)\end{array}$ & $\begin{array}{c}-53.457 * * * \\
(-6.475)\end{array}$ \\
\hline Geodiv & $\begin{array}{c}-5.667 * * \\
(-2.271)\end{array}$ & $\begin{array}{c}-1.943 \\
(-0.790)\end{array}$ & $\begin{array}{l}-26.446 \\
(-1.441)\end{array}$ & $\begin{array}{c}3.556 \\
(1.097)\end{array}$ & $\begin{array}{r}-9.079 * \\
(-1.870)\end{array}$ \\
\hline Invest & $\begin{array}{c}7.853 * * \\
(2.423)\end{array}$ & $\begin{array}{c}7.374 * * \\
(2.249)\end{array}$ & $\begin{array}{l}10.873 \\
(1.620)\end{array}$ & $\begin{array}{l}2.927 \\
(0.937)\end{array}$ & $\begin{aligned} &-15.720 * * \\
&(-1.980)\end{aligned}$ \\
\hline GDP & $\begin{array}{l}-0.089 \\
(-0.162)\end{array}$ & $\begin{array}{c}-0.124 \\
(-0.246)\end{array}$ & $\begin{array}{c}0.246 \\
(0.525)\end{array}$ & $\begin{array}{c}-0.192 \\
(-0.239)\end{array}$ & $\begin{array}{c}-0.130 \\
(-0.120)\end{array}$ \\
\hline Interest & $\begin{array}{c}0.046 \\
(0.065)\end{array}$ & $\begin{array}{c}0.286 \\
(0.575)\end{array}$ & $\begin{array}{c}0.298 \\
(0.735)\end{array}$ & $\begin{array}{c}0.997 \\
(1.018)\end{array}$ & $\begin{array}{c}0.985 \\
(0.743)\end{array}$ \\
\hline Constant & $\begin{array}{c}18.708 * \\
(1.817)\end{array}$ & $\begin{array}{l}13.957 \\
(1.353)\end{array}$ & $\begin{array}{l}22.406 \\
(1.555)\end{array}$ & $\begin{array}{c}24.317 * * \\
(2.149)\end{array}$ & $\begin{array}{c}67.337 * * * \\
(3.376)\end{array}$ \\
\hline Sample size & 297 & 186 & 105 & 81 & 111 \\
\hline
\end{tabular}

Note. (1) $* * *$ means $p<0.01, * *$ means $p<0.05$, and $*$ means $p<0.1$. (2) Below the estimated coefficient () is a robust standard error.

TABLE 13: The endogeneity test of the mediating effect of profitability.

\begin{tabular}{|c|c|c|c|c|}
\hline \multirow[b]{2}{*}{ Variables } & \multicolumn{2}{|c|}{ Small Chinese-funded } & \multicolumn{2}{|c|}{ Foreign-funded } \\
\hline & $\begin{array}{c}\text { Roa } \\
(1)\end{array}$ & $\begin{array}{c}\text { Solvency } \\
\text { (2) }\end{array}$ & $\begin{array}{c}\text { Roa } \\
(3)\end{array}$ & $\begin{array}{c}\text { Solvency } \\
(4)\end{array}$ \\
\hline Roa & & $\begin{array}{c}-1.419 \\
(-0.130) \\
\end{array}$ & & $\begin{array}{l}21.500 \\
(1.406) \\
\end{array}$ \\
\hline Nonauto & $\begin{array}{c}0.009 \\
(0.275) \\
\end{array}$ & $\begin{array}{c}11.423 * * \\
(2.115) \\
\end{array}$ & $\begin{array}{c}0.118 * * * \\
(5.623)\end{array}$ & $\begin{array}{c}3.691 \\
(0.969)\end{array}$ \\
\hline Size & $\begin{array}{c}0.031 * * * \\
(3.714)\end{array}$ & $\begin{array}{c}-0.721 \\
(-0.936)\end{array}$ & $\begin{array}{c}0.072 * * * \\
(6.000)\end{array}$ & $\begin{array}{r}-4.241 * \\
(-1.847)\end{array}$ \\
\hline Loss & $\begin{array}{c}0.050 \\
(1.553) \\
\end{array}$ & $\begin{array}{c}-3.270 \\
(-0.925) \\
\end{array}$ & $\begin{array}{c}-0.011 \\
(-1.484) \\
\end{array}$ & $\begin{array}{c}2.522 * * * \\
(2.692)\end{array}$ \\
\hline Lev & $\begin{array}{c}-0.052 * * \\
(-2.261) \\
\end{array}$ & $\begin{array}{c}-28.785 * * * \\
(-7.578)\end{array}$ & $\begin{array}{c}-0.148 * * * \\
(-4.161)\end{array}$ & $\begin{array}{c}-50.749 * * * \\
(-5.613)\end{array}$ \\
\hline Geodiv & $\begin{array}{c}-0.022 \\
(-1.139) \\
\end{array}$ & $\begin{array}{c}3.525 \\
(1.108) \\
\end{array}$ & $\begin{array}{c}-0.032 \\
(-1.165) \\
\end{array}$ & $\begin{array}{r}-8.451 * \\
(-1.763) \\
\end{array}$ \\
\hline Invest & $\begin{array}{c}0.028 \\
(1.151)\end{array}$ & $\begin{array}{c}2.962 \\
(0.941)\end{array}$ & $\begin{array}{c}0.002 \\
(0.038)\end{array}$ & $\begin{array}{c}-16.328 * * \\
(-2.128)\end{array}$ \\
\hline GDP & $\begin{array}{c}-0.001 \\
(-0.157)\end{array}$ & $\begin{array}{c}-0.192 \\
(-0.239) \\
\end{array}$ & $\begin{array}{c}0.003 \\
(0.550) \\
\end{array}$ & $\begin{array}{c}-0.258 \\
(-0.244) \\
\end{array}$ \\
\hline Interest & $\begin{array}{c}-0.010 \\
(-1.444)\end{array}$ & $\begin{array}{c}0.989 \\
(1.019) \\
\end{array}$ & $\begin{array}{c}-0.004 \\
(-0.645) \\
\end{array}$ & $\begin{array}{c}1.036 \\
(0.796) \\
\end{array}$ \\
\hline Constant & $\begin{array}{c}-0.222 * * \\
(-2.346)\end{array}$ & $\begin{array}{c}23.972 * \\
(1.926) \\
\end{array}$ & $\begin{array}{c}-0.555 * * * \\
(-4.827)\end{array}$ & $\begin{array}{c}80.860 * * * \\
(3.649)\end{array}$ \\
\hline Sample size & 83 & 81 & 135 & 111 \\
\hline
\end{tabular}

Note. (1) $* * *$ means $p<0.01, * *$ means $p<0.05$, and $*$ means $p<0.1$. (2) Below the estimated coefficient () is a robust standard error.

TABLE 14: The endogeneity test of the mediating effect of reinsurance behavior.

\begin{tabular}{|c|c|c|c|c|}
\hline \multirow[b]{2}{*}{ Variables } & \multicolumn{2}{|c|}{ Small Chinese-funded } & \multicolumn{2}{|c|}{ Foreign-funded } \\
\hline & $\begin{array}{c}\text { Rein } \\
(1)\end{array}$ & $\begin{array}{c}\text { Solvency } \\
(2)\end{array}$ & $\begin{array}{c}\text { Rein } \\
(3)\end{array}$ & $\begin{array}{c}\text { Solvency } \\
(4)\end{array}$ \\
\hline Rein & & $\begin{array}{c}19.319 * * * \\
(2.707) \\
\end{array}$ & & $\begin{array}{c}33.709 * * * \\
(7.702)\end{array}$ \\
\hline Nonauto & $\begin{array}{r}0.177 * \\
(1.941)\end{array}$ & $\begin{array}{l}8.137 * \\
(1.699)\end{array}$ & $\begin{array}{c}0.384 * * * \\
(5.482)\end{array}$ & $\begin{array}{c}-2.656 \\
(-0.667)\end{array}$ \\
\hline
\end{tabular}


TABle 14: Continued.

\begin{tabular}{|c|c|c|c|c|}
\hline \multirow[b]{2}{*}{ Variables } & \multicolumn{2}{|c|}{ Small Chinese-funded } & \multicolumn{2}{|c|}{ Foreign-funded } \\
\hline & $\begin{array}{l}\text { Rein } \\
(1)\end{array}$ & $\begin{array}{c}\text { Solvency } \\
\text { (2) }\end{array}$ & $\begin{array}{c}\text { Rein } \\
(3)\end{array}$ & $\begin{array}{l}\text { Solvency } \\
\text { (4) }\end{array}$ \\
\hline Size & $\begin{array}{c}-0.013 \\
(-0.807) \\
\end{array}$ & $\begin{array}{c}-0.557 \\
(-0.838) \\
\end{array}$ & $\begin{array}{c}-0.009 \\
(-0.268) \\
\end{array}$ & $\begin{array}{c}-2.291 \\
(-1.440) \\
\end{array}$ \\
\hline Loss & $\begin{array}{c}-0.014 \\
(-0.192)\end{array}$ & $\begin{array}{c}-3.067 \\
(-0.958)\end{array}$ & $\begin{array}{c}0.009 \\
(0.738)\end{array}$ & $\begin{array}{l}1.748 * \\
(1.703)\end{array}$ \\
\hline Lev & $\begin{array}{c}0.166 * * * \\
(2.831)\end{array}$ & $\begin{array}{c}-32.062 * * * \\
(-8.109)\end{array}$ & $\begin{array}{c}0.106 \\
(0.862)\end{array}$ & $\begin{array}{c}-57.352 * * * \\
(-7.195)\end{array}$ \\
\hline Geodiv & $\begin{array}{r}-0.091 * \\
(-1.673) \\
\end{array}$ & $\begin{array}{r}5.402 * \\
(1.788) \\
\end{array}$ & $\begin{array}{c}-0.207 * * \\
(-2.279)\end{array}$ & $\begin{array}{c}-2.781 \\
(-0.693)\end{array}$ \\
\hline Invest & $\begin{array}{c}0.012 \\
(0.281) \\
\end{array}$ & $\begin{array}{c}2.709 \\
(0.950) \\
\end{array}$ & $\begin{array}{c}-0.664 * * * \\
(-4.692)\end{array}$ & $\begin{array}{c}7.687 \\
(1.116)\end{array}$ \\
\hline GDP & $\begin{array}{c}-0.004 \\
(-0.335) \\
\end{array}$ & $\begin{array}{c}-0.099 \\
(-0.141) \\
\end{array}$ & $\begin{array}{c}0.006 \\
(0.295)\end{array}$ & $\begin{array}{c}-0.339 \\
(-0.392)\end{array}$ \\
\hline Interest & $\begin{array}{c}-0.017 \\
(-1.338) \\
\end{array}$ & $\begin{array}{c}1.328 \\
(1.398) \\
\end{array}$ & $\begin{array}{c}-0.004 \\
(-0.179)\end{array}$ & $\begin{array}{c}1.282 \\
(1.178) \\
\end{array}$ \\
\hline Constant & $\begin{array}{c}0.224 \\
(1.300)\end{array}$ & $\begin{array}{c}19.940 * * \\
(2.058)\end{array}$ & $\begin{array}{c}0.428 \\
(1.248)\end{array}$ & $\begin{array}{c}49.977 * * * \\
(3.024)\end{array}$ \\
\hline Sample size & 83 & 81 & 135 & 111 \\
\hline
\end{tabular}

Note. (1) $* * *$ means $p<0.01, * *$ means $p<0.05$, and $*$ means $p<0.1$. (2) Below the estimated coefficient () is a robust standard error.

conclusion of this paper is still valid after endogeneity test.

\section{Conclusions and Implications}

This paper studies the theoretical mechanism of the impact of the business structure on solvency of $\mathrm{P} / \mathrm{L}$ insurance companies and conducts an empirical test based on the manually collected solvency adequacy data of $\mathrm{P} / \mathrm{L}$ insurance companies from 2009 to 2015 by using a mediating effect model.

The results show the following: first, the business structure of $\mathrm{P} / \mathrm{L}$ insurance companies with different ownerships and different scales has different impacts on solvency. The increase in the proportion of nonauto insurance business of small Chinese-funded companies will significantly enhance their solvency, but not for large Chinesefunded companies. The increase in the proportion of auto insurance business of foreign-funded $\mathrm{P} / \mathrm{L}$ insurance companies will significantly reduce their solvency.

Second, through the stepwise regression method, we empirically test the mediating effect of profitability and reinsurance behavior. It is found that no matter for small Chinese-funded companies or foreign-funded companies, the mediating effect of profitability does not exist. When the business structure of nonauto insurance business is relatively high, $\mathrm{P} / \mathrm{L}$ insurance companies tend to increase the reinsurance ceding ratio to enhance their solvency.

Third, the bootstrap method was further used to estimate the multiple mediating effects of profitability and reinsurance behavior and their influence degree. It was found that the mediating effect of profitability did not exist. However, the mediating effect of reinsurance in small Chinese-funded companies is a partial mediating effect, and the mediating effect value is 55.875 , accounting for $52.36 \%$ of the total effect, while the mediating effect of reinsurance behavior in foreign-funded $\mathrm{P} / \mathrm{L}$ insurance companies is a complete mediating effect, and the effect value is 53.127.

In view of the above conclusions, this paper puts forward the following suggestions.

Firstly, in the background of China's insurance industry supply-side reform, small Chinese-funded companies should seize the opportunity and actively adjust their business development strategies to prevent the adverse impact on solvency caused by the excessive concentration of underwriting risks in the auto insurance business. As we all know, compared with auto insurance business, nonauto insurance business has more complex risk sources and risk carriers and higher requirements for underwriting and claim settlement. Therefore, small Chinese-funded P/L insurance companies should actively introduce talents related to the product design, claim settlement, and risk control of nonauto insurance and strengthen the training of employees on nonauto insurance knowledge. In addition, small Chinesefunded companies should abide by the Guidelines on Insurance Product Development for Property-Liability Insurance Companies, attach importance to reinsurance ceding work, transfer the risks and responsibilities higher than the company's ability to bear to reinsurance companies through appropriate reinsurance arrangements, control the accumulation of liabilities and the amount of loss compensation, and enhance their solvency.

Secondly, the development of foreign-funded companies' auto insurance business in China's insurance market does not enhance their solvency by improving their profitability, which may be related to the fact that foreign-funded companies lack market experience and data accumulation in China's auto insurance business, and the marketing network 
layout is difficult to develop in a short period of time. Foreign-funded companies in China should prudently and selectively develop their auto insurance business, give full play to their advantages in characteristic claim service and high-priced auto underwriting, take the road of differentiated competition, and improve the profitability of auto insurance business. Alternatively, foreign-funded $\mathrm{P} / \mathrm{L}$ insurance companies can choose to unswervingly operate nonauto insurance business. Foreign-funded $\mathrm{P} / \mathrm{L}$ insurance companies can reduce the policy acquisition cost through professional and centralized operation, give full play to the advantages of nonauto insurance business, and provide better risk management services for customers.

Finally, insurance regulatory authorities need to innovate the supervision mode of nonauto insurance business and conduct regular inspection of reinsurance ceding of nonauto insurance business of $\mathrm{P} / \mathrm{L}$ insurance companies to prevent solvency risks.

\section{Data Availability}

The data used to support the findings of this study are available from the corresponding author upon request.

\section{Conflicts of Interest}

The authors declare that they have no conflicts of interest.

\section{Acknowledgments}

This paper was supported by the Fundamental Research Funds for the Central Universities (Humanities and Social Sciences Research Project of Wuhan University).

\section{References}

[1] S. E. Harrington and J. M. Nelson, "A regression-based methodology for solvency survellance in the property-liability insurance industry," The Journal of Risk and Insurance, vol. 53, no. 4, pp. 583-605, 1986.

[2] B. Zhu, X. H. Wu, and A. W. Zhang, "An empirical analysis of the factors affecting the solvency of property insurance companies in China," Insurance Studies, vol. 28, no. 5, pp. 33-37, 2008.

[3] S. Z. Jiang and Y. H. Liu, "Impact of unbalanced product mix on capital structure, profitability and solvency of life insurance companies," Insurance Studies, vol. 32, no. 3, pp. 45-53, 2012.

[4] H. I. Ansoff, "Strategies for diversification," Harvard Business Review, vol. 33, no. 5, pp. 113-124, 1957.

[5] R. Teyssier, "Economies of scale and economies of diversification in insurance business: some elements of valuation," The Geneva Papers on Risk and Insurance - Issues and Practice, vol. 16, no. 3, pp. 327-338, 1991.

[6] J. W. Meador, H. E. Ryan, C. D. Schellhorn, and A. M. Santomero, "Product focus versus diversification: estimates of X-efficiency for the US life insurance industry," Center for Financial Institutions Working Papers, vol. 32, 1997.

[7] M. Pervan, T. Pavic Kramaric, Effects of market share and diversification on nonlife insurers' performance," International Journal of Social \& Human Sciences, vol. 42, no. 1, pp. 126-145, 2012.
[8] R. E. Hoyt and J. S. Trieschmann, "Risk/return relationships for life-health, property-liability, and diversified insurers: reply," The Journal of Risk and Insurance, vol. 59, no. 4, pp. 687-689, 1992.

[9] J. D. Cummins and G. P. Nini, "Optimal capital utilization by financial firms: evidence from the property-liability insurance industry," Journal of Financial Services Research, vol. 21, no. 1, pp. 15-53, 2002.

[10] J. D. Cummins, M. A. Weiss, X. Xie, and H. Zi, "Economies of scope in financial services: a DEA efficiency analysis of the US insurance industry," Journal of Banking \& Finance, vol. 34, no. 7, pp. 1525-1539, 2010.

[11] J. Shim, "Mergers \& acquisitions, diversification and performance in the u.s. property-liability insurance industry," Journal of Financial Services Research, vol. 39, no. 3, pp. 119-144, 2011.

[12] B. Elango, Y.-L. Ma, and N. Pope, "An investigation into the diversification-performance relationship in the U.S. propertyliability insurance industry," Journal of Risk \& Insurance, vol. 75, no. 3, pp. 567-591, 2008.

[13] J. M. Ambrose and J. A. Seward, "Best's ratings, financial ratios and prior probabilities in insolvency prediction," The Journal of Risk and Insurance, vol. 55, no. 2, pp. 229-244, 1988.

[14] D. Leadbetter and S. Dibra, "Why insurers fail: the dynamics of property and casualty insurance insolvency in Canada," The Geneva Papers on Risk and Insurance-Issues and Practice, vol. 33, no. 3, pp. 464-488, 2008.

[15] A. E. Kleffner and R. B. Lee, "An examination of property \& casualty insurer solvency in Canada," Journal of Insurance Issues, vol. 32, no. 1, pp. 52-77, 2009.

[16] R. Yakob, Z. Yusop, A. Radam, and N. Ismail, "Solvency determinants of conventional life insurance and takaful operators," Asia-Pacific Journal of Risk and Insurance, vol. 6, no. 2, 2012.

[17] L. Z. Li and W. Lu, "Factor Analysis of the performance of property insurance companies," Management Sciences in China, vol. 16, no. 3, pp. 46-50, 2003.

[18] L. L. Zheng, "Research of the Elements influencing the solvency of insurance companies in China," Scientific Decision Making, vol. 20, no. 5, pp. 72-82, 2014.

[19] W. Li and S. S. Gu, "An empirical analysis of the factors affecting the solvency of property insurance companies in China," Journal of Insurance Professional College(Bimonthly), vol. 32, no. 6, pp. 19-23, 2018.

[20] D. Mayers and C. W. Smith, "On the corporate demand for insurance: evidence from the reinsurance market," Journal of Business, vol. 63, no. 1, pp. 19-40, 1990.

[21] M. Curak, M. Pervan, and T. P. Kramaric, "Factors influencing the demand for reinsurance," in Proceedings of The 8th International Days of Statistics and Economic, no. 9, pp. 297-307, Prague, Czech Republic, September2014.

[22] S. Mankaï and A. Belgacem, "Interactions between risk taking, capital, and reinsurance for property-liability insurance firms," Journal of Risk \& Insurance, vol. 83, no. 4, pp. 1007-1043, 2016.

[23] L. C. Wu, S. G. Shen, and L. Wang, "Reinsurance demand and its determinants of the P.R.China's property-casualty insurance industry - evidence from panel data," Collected Essays on Finance and Economics, vol. 151, no. 3, pp. 64-70, 2010.

[24] G. Q. Zhao and H. Wu, "Reinsurance decision-making motivation of China's property-liability insurance companies: an empirical analysis based on quantile regression method," Collected Essays on Finance and Economics, vol. 153, no. 3, pp. 64-70, 2010. 
[25] H. Chen and Y. G. Ding, "A study on capital structure, business concentration and reinsurance demand of insurance companies," Modern Finance and Economics, vol. 36, no. 6, pp. 56-65, 2016.

[26] H. Lin, H. Ping, and Z. Liang, "Optimal control of the insurance company with proportional reinsurance policy under solvency constraints," Insurance: Mathematics and Economics, vol. 43, no. 3, pp. 474-479, 2008.

[27] Z. Liang and J. Huang, "Optimal dividend and investing control of an insurance company with higher solvency constraints," Insurance: Mathematics and Economics, vol. 49, no. 3, pp. 501-511, 2010.

[28] Y. Huang and H. Y. Wang, "Contrastive analysis of solvency influencing factors of China's property and life insurance companies," Economic Forum, vol. 25, no. 3, pp. 129-133, 2011.

[29] W. L. Bian and X. N. Wang, "The effects of investment function on insurers' risk," Journal of Financial Research, vol. 60 , pp. 158-173, 2017.

[30] J. F. Hao, "Product concentration, comprehensive expense ratio and performance - an empirical study based on the nonlife insurance companies in China," Shanghai Finance, vol. 32, pp. 30-34, 2012.

[31] W. J. Sun and H. Y. Cui, "An empirical study on the relationship between risks and capital for insurance in China-Cbased on the methods of 2SLS and 2SQR," Audit Economy Research, vol. 32, no. 1, pp. 104-116, 2017.

[32] X. M. Peng and Z. F. Zeng, "Market concentration of the insurance industry and corporate financial stability-based on the data of China's property insurance industry," Insurance Studies, vol. 359, no. 3, pp. 42-58, 2018.

[33] R. Baron and D. A. Kenny, "The moderator-mediator variable distinction in social psychological research: conceptual, strategic and statistical considerations," Journal of Personality and Social Psychology, vol. 51, no. 6, pp. 1173-1182, 1985.

[34] Z. Wen and B. Ye, "Analyses of mediating effects: the development of methods and models," Advances in Psychological Science, vol. 22, no. 5, pp. 731-745, 2014.

[35] K. J. Preacher and A. F. Hayes, "Asymptotic and resampling strategies for assessing and comparing indirect effects in multiple mediator models," Behavior Research Methods, vol. 40, no. 3, pp. 879-891, 2008.

[36] J. C. Driscoll and A. C. Kraay, "Consistent covariance matrix estimation with spatially dependent panel data," The Review of Economics and Statistics, vol. 80, no. 4, pp. 549-560, 1998.

[37] D. Hoechle, "Robust standard errors for panel regressions with cross-sectional dependence," The Stata Journal: Promoting communications on statistics and Stata, vol. 7, no. 3, pp. 281-312, 2007. 